\title{
Effects of zooplankton carcasses degradation on freshwater bacterial community composition and implications for carbon cycling
}

Olesya V. Kolmakova (1) https://orcid.org/0000-0003-2694-7545, Michail I. Gladyshev (1) https://orcid.org/0000-00032276-3095, Jérémy André Fonvielle (1) https://orcid.org/0000-0002-8077-2419, Lars Ganzert, Thomas Hornick (1) https://orcid.org/0000-0003-0280-9260, Hans-Peter Grossart (10 https://orcid.org/0000-0002-9141-0325

DOI

$\underline{10.1111 / 1462-2920.14418}$

Original publication date

24 September 2018

Document version

Accepted version

Published in

Environmental Microbiology

\section{Citation (Vancouver)}

Kolmakova OV, Gladyshev MI, Fonvielle JA, Ganzert L, Hornick T, Grossart H-P. Effects of zooplankton carcasses degradation on freshwater bacterial community composition and implications for carbon cycling. Environmental Microbiology. 2019;21(1):34-49. 
1 Effects of zooplankton carcasses degradation on freshwater bacterial community

2 composition and implications for carbon cycling

3 Olesya V. Kolmakova ${ }^{1,2,3^{*}}$, Michail I. Gladyshev ${ }^{1,2}$, Jérémy André Fonvielle ${ }^{3}$, Lars

4 Ganzert $^{3,4,5}$, Thomas Hornick ${ }^{3}$ and Hans-Peter Grossart ${ }^{3,6}$

$5{ }^{1}$ Institute of Biophysics of Siberian Branch of Russian Academy of Sciences,

6 Akademgorodok, 660036 Krasnoyarsk, Russia

$7 \quad{ }^{2}$ Siberian Federal University, Svobodny av. 79, 660041 Krasnoyarsk, Russia

$8 \quad{ }^{3}$ Leibniz-Institute of Freshwater Ecology and Inland Fisheries (IGB), Department of

9 Experimental Limnology, Alte Fischerhütte 2, 16775 Stechlin, Germany.

${ }^{4}$ GFZ German Research Centre for Geosciences, Helmholtz Centre Potsdam, Section 5.3

11 Geomicrobiology, 14473, Potsdam, Germany.

$12{ }^{5}$ University of Göttingen, Experimental Phycology and Culture Collection of Algae (SAG),

13 Nikolausberger Weg 18, 37073 Göttingen, Germany.

${ }^{6}$ University of Potsdam, Institute of Biochemistry and Biology, Am Neuen Palais 10, 14469

15 Potsdam, Germany.

*Corresponding author: kolmoles@ibp.krasn.ru, ORCID 0000-0003-2694-7545

17 Running title: Effect of dead zooplankton on bacteria and C-cycle 


\section{Originality-Significance Statement}

In a recent comprehensive review on the role of zooplankton in the aquatic carbon cycle, Steinberg and Landry (2017) state that the carbon input via carcasses, in spite of their abundance, remains largely unknown. Our study is the first to cast light upon this important yet overlooked organic matter source for microorganisms in aquatic systems. Our study reveals that decomposing zooplankton carcasses could be a major driver of bacterial community composition in many aquatic ecosystems, e.g. in lakes with an inverted biomass pyramid and in common events of mass zooplankton mortality. Using stable isotope labeling we show that zooplankton carcasses are well degraded by heterotrophic prokaryotes indicating their labile nature, but do not significantly stimulate the degradation of more refractory organic matter such as humic matter. Thus, carcasses are important hotspots of microbial activity influencing the organic matter sinking flux and overall microbial diversity in aquatic ecosystems. 


\section{Summary}

Non-predatory mortality of zooplankton provides an abundant, yet, little studied source of high quality labile organic matter (LOM) in aquatic ecosystems. Using laboratory microcosms, we followed the decomposition of organic carbon of fresh ${ }^{13} \mathrm{C}$-labelled Daphnia carcasses by natural bacterioplankton. The experimental setup comprised blank microcosms i.e. artificial lake water without any organic matter additions (B), and microcosms either amended with natural humic matter $(\mathbf{H})$, fresh Daphnia carcasses (D) or both, i.e. humic matter and Daphnia carcasses (HD). Most of the carcass carbon was consumed and respired by the bacterial community within 15 days of incubation. A shift in the bacterial community composition shaped by labile carcass carbon and by humic matter was observed. Nevertheless, we did not observe a quantitative change in humic matter degradation by heterotrophic bacteria in the presence of LOM derived from carcasses. However, carcasses were the main factor driving the bacterial community composition suggesting that the presence of large quantities of dead zooplankton might affect the carbon cycling in aquatic ecosystems. Our results imply that organic matter derived from zooplankton carcasses is efficiently remineralized by a highly specific bacterial community, but doesn't interfere with the bacterial turnover of more refractory humic matter. 


\section{Introduction}

The global carbon cycle is one of the most important biogeochemical processes regulating the climate on our planet (Ward et al., 2013). In particular, carbon fluxes between aquatic and terrestrial ecosystems constitute a key component of global biogeochemical cycles (Pace et al., 2004; Battin et al., 2009; Ward et al., 2013). Nowadays, it is well known that a significant part of terrigenous organic matter drains from soils into aquatic ecosystems, especially in the boreal zone (Vachon et al., 2017). Freshwaters are considered hotspots of organic matter degradation, sustaining a shorter half-life of organic carbon compared to terrestrial and marine ecosystems (Catalán et al., 2015). In freshwaters, organic matter comprises a heterogeneous mixture of different carbon sources with varying degradability. Depending on their degradability by aquatic microbes, the drained terrigenous organic matter is buried to a variable extent in sediments of aquatic ecosystems (Tranvik et al., 2009). However, most of the terrigenous (allochthonous) organic carbon is transported into aquatic ecosystems in the form of refractory organic matter (ROM) resulting in a generally higher retention time due to its slow decomposition by aquatic microorganisms (Bianchi, 2011). A major part of this ROM in freshwater ecosystems is represented by humic matter (Rocker et al., 2012a).

Bacterial species differ in their response to various sources of carbon resulting in profound implications for aquatic carbon cycling. It has been demonstrated that the availability of organic matter promotes growth of both generalist species, which are able to degrade a wide range of substrates, as well as highly specialized populations degrading specific substrate fractions (Hutalle-Schmelzer et al., 2010). Dead zooplankton, which used to be generally neglected in aquatic ecology due to methodological limitations (Tang et al., $2009,2014)$, is an overlooked and highly abundant source of labile carbon in most freshwater ecosystems. Zooplankton carcasses represent a high quality organic substrate for 
heterotrophic bacteria due to their relatively low $\mathrm{C}: \mathrm{N}: \mathrm{P}$ ratio as compared to phytoplankton and detritus (Tang et al., 2014). Consequently, zooplankton carcasses are "hot spots" of activity of pelagic microorganisms consuming labile organic matter (LOM) as well as ROM (Tang et al., 2006; Grossart et al., 2007; Elliott et al., 2010; Kirillin et al., 2012). However, zooplankton carcasses provide not only a carbon source for microorganisms, but also surfaces for attachment. Microorganisms attached to particles are situated in close spatial proximity and can benefit from extracellular degradation enzymes released in the environment (Catalán et al., 2015). Thus, attached microorganisms have a higher capacity to degrade polymeric organic matter than their free living counterparts (Grossart, 2010). Consequently, zooplankton carcasses are selecting for specific, but yet uncharacterized microbial communities (Tang et al., 2010). The complex LOM of zooplankton carcasses constitutes a valuable source of nutrients and energy for microorganisms, thus implying effects on aquatic carbon cycling, in particular of the more refractory carbon pools. For instance, carcass LOM may induce a "priming effect" and facilitate the degradation of ROM (Bianchi, 2011).

Thus, our primary objective was to investigate consequences on bacterial community composition and carbon cycling in aquatic ecosystems after input of zooplankton carcasses. Since the quality of available organic matter can be a selective force for bacterioplankton community composition (Gómez-Consarnau et al., 2012), we tested the hypothesis that nutrient-rich LOM provided by Daphnia carcasses selects for generalist bacteria in contrast to C-rich ROM selecting to a larger extent for specialists. In a microcosms experiment, we observed the degradation of ${ }^{13} \mathrm{C}$-labeled carcasses by heterotrophic bacteria from a dystrophic humic bog lake in the presence of indigenous humic matter (treatment HD) to track the fate of carcass carbon (Fig. S1). In parallel, we followed three control treatments with either Daphnia carcasses (D) or humic matter (H) as a sole carbon source, and a blank treatment (B) containing solely a natural bacterial community. We used optical properties (specific UV absorbance at $254 \mathrm{~nm}-\mathrm{SUVA}_{254}$, humification index, etc.) and size exclusion 
chromatography to analyze the influence of carcasses on the dissolved organic matter (DOM) pool and combined it with $16 \mathrm{~S}$ rRNA gene Illumina amplicon sequencing to characterize the bacterial community composition in detail.

\section{Results}

\section{Microbial dynamics and community composition}

Daphnia carcasses showed a rapid decomposition during the first week of incubation, with visible changes in the state of carcasses over time (Fig. S2a-d). At the end of the experiment, the carcasses were still visible as disintegrated parts of the carapace. Dense bacterial colonization of the carcasses was observed (Fig. S2e), while protist grazers or autotrophic organisms were not detected indicating that protozoan grazers and large phytoplankton have been successfully removed by the pre-filtration step. No differences in bacterial counts were observed in the $\mathbf{B}$ microcosms between the start and the end of the experiment (Table 1). However, a clear increase in bacterial cells counts was observed in $\mathbf{H}$, D and HD microcosms (43\%, 654\% and 617\%, respectively; Table 1). This indicated a higher bacterial growth in the presence of Daphnia carcasses and a slower growth on humic matter alone. At the same time, bacterial cell counts did not significantly differ between HD and D microcosms (paired t-test, $\mathrm{p}>0.05$, Table 1).

After sequencing and performing a quality check for all samples, 595036 reads of $16 \mathrm{~S}$ rRNA gene fragments were obtained that clustered into 1161 bacterial operational taxonomic units (OTUs). The identified OTUs belonged to 26 known phyla (Fig. 1). In the initial bacterial inoculum from Lake Grosse Fuchskuhle, Proteobacteria was the dominant phylum ( $48 \%$ of all sequences), with a high proportion of the class Betaproteobacteria $(30 \%$ of all sequences). By the end of the experiment, the relative abundance of Proteobacteria increased 
in all treatments, especially in carcasses amended microcosms (HD and D; Fig. 1), with a dominance of the class Gammaproteobacteria (62\% and $50 \%$ in HD and D respectively).

At the end of the experiment, the microcosms HD and D had a lower OTU richness and evenness compared to microcosms without added carcasses ( $\mathbf{H}$ and $\mathbf{B}$; Table 2). Microcosms $\mathbf{H}$ had lower species richness than $\mathbf{B}$ microcosms, but showed a higher evenness (Table 2).

In an unconstrained ordination (Fig. 2), all treatments were distinguishable from one another and from the initial inoculum (ANOSIM, $\mathrm{R}=0.835, \mathrm{p}=0.001$ ). The OTUs accounting for most of the difference between the treatments were identified using a SIMPER test (Table 3). The relative abundance of the most influential OTU (OTU1, Pseudomonas sp.) was significantly different between the start and the end of the incubation for all treatments (ANOVA $\mathrm{F}_{4,15}=102.89, \mathrm{p}<0.001$ ). The distribution of different OTUs in all treatments is discussed in more details in the Supplementary Information.

\section{DOM composition and fate of carcass carbon}

We aimed to test for the "priming effect" by comparing the predicted total organic carbon degradation rate $(\triangle \mathrm{TOC})$ in $\mathrm{HD}$ microcosms, calculated from $\Delta \mathrm{TOC}$ in the control microcosms $\mathbf{D}, \mathbf{H}$, and $\mathbf{B}$, to the measured $\triangle \mathrm{TOC}$ in $\mathbf{H D}$ microcosms (see Supplementary Methods for more details). The predicted $\triangle \mathrm{TOC}$ was $-1.015 \pm 0.115 \mathrm{mg} \mathrm{L}^{-1}$ and did not differ significantly (paired t-test, $\mathrm{p}>0.05)$ from the $\triangle \mathrm{TOC}$ measured in HD microcosms $(-1.094 \pm$ $\left.0.057 \mathrm{mg} \mathrm{L}^{-1}\right)$.

During carcass decomposition (in HD and D microcosms only), the particulate organic carbon (POC) decreased approximately four-fold compared to the initial values (Table 1). Nevertheless, no significant differences in concentrations of dissolved organic carbon (DOC), high- and low-molecular weight substances (HMWS and LMWS, respectively) or humic substances were found throughout the experiment in any treatment (paired t-tests, $p>0.05$ in 
all tests, Table 1). However, in ROM supplemented microcosms (HD and H) we observed trends of decreasing concentrations in polysaccharides, amphiphilic molecules, and building blocks of humic substances (Table 1).

The $\mathrm{SUVA}_{254}$, spectral slopes and optical indices values were not different between the humic-amended microcosms $\mathbf{H}$ and $\mathbf{H D}$ (Table 1), and they did not differ between $\mathbf{D}$ and B microcosms (Table 1). An exception was the freshness index, being an indicator for recently produced DOM (Hansen et al., 2016), which was lower in D compared to B microcosms. Expectedly, the ratio of peakA to peakT, which is known as an indicator of the ratio of humic-like (recalcitrant) to freshly produced (labile) organic matter (Hansen et al., 2016), was higher in $\mathbf{H}$ microcosms compared to HD (Wilcoxon test, p-value $=0.03$ ).

The carcasses had an average ${ }^{13} \mathrm{C} /{ }^{12} \mathrm{C}$ ratio of $0.168 \pm 0.004\left(\delta^{13} \mathrm{C}=13945.3 \pm\right.$ $303.9 \%$ ). According to this specific signature, the amount of processed carbon originating from the carcasses was computed in all carcass-containing microcosms (i.e. HD and D). In HD microcosms, $72.8 \%$ of POC and $2.2 \%$ of DOC originated from Daphnia carcasses, against $82.1 \%$ of POC and $21.1 \%$ of DOC for the D microcosms (Fig. 3).

The bacterial respiration, measured as the increase in $\mathrm{CO}_{2}$ and normalized to the background respiration (i.e. respiration from the blank microcosms B) was higher in D microcosms compared to $\mathbf{H}$ but lower compared to HD microcosms (Fig. S3). The respiration per amount of initially added carbon and normalized to the background respiration was higher in $\mathbf{H D}$ microcosms compared to $\mathbf{H}$ but lower compared to $\mathbf{D}$ microcosms, and was used to confirm the labile character of the organic matter originating from the zooplankton carcasses. All differences in $\mathrm{CO}_{2}$ concentrations between the microcosms were significant (1-way ANOVA $\mathrm{F}=241.6, \mathrm{p}<0.001$; Tukey post hoc test $\mathrm{p}<0.01$ for all pairs).

To test for the priming effect, the predicted ${ }^{13} \mathrm{C} /{ }^{12} \mathrm{C}$ ratio in the respired $\mathrm{CO}_{2}$ of $\mathrm{HD}$ microcosms was calculated from the values in the control microcosms $\mathbf{D}, \mathbf{H}$, and $\mathbf{B}$, and compared to the measured ${ }^{13} \mathrm{CO}_{2} /{ }^{12} \mathrm{CO}_{2}$ ratio in $\mathbf{H D}$ microcosms (see Supplementary Methods 
173 for more details). The predicted ${ }^{13} \mathrm{CO}_{2} /{ }^{12} \mathrm{CO}_{2}$ ratio for $\mathrm{HD}(0.078 \pm 0.003)$ did not differ

174 significantly (paired t-test, $\mathrm{p}>0.05)$ from the measured value $(0.073 \pm 0.003)$. In HD 175 microcosms, $87.8 \pm 6.3 \%$ of respired $\mathrm{CO}_{2}$ originated from zooplankton carcasses when 176 normalized to the background respiration of microcosms $\mathbf{B}$.

\section{Interactions between microbial community and DOC quality}

The interactions between bacterial community composition and DOC quality in microcosms HD, H, and D revealed specific patterns in bacterial substrate preferences (Fig. 4). The connections between bacterial genera and DOC qualities significantly differed between microcosms $\mathbf{H}$ and $\mathbf{D}$ (Fig. 4a). Thus, bacteria positively interacting with DOC concentration as well as humification and fluorescence indices are the ones thriving in the presence of humic matter (Fig. 4a). On the contrary, bacteria negatively associated with these parameters are favored by carcasses (Fig. 4a). Similarly, genera positively correlated with DOC concentration, fluorescence index and $\mathrm{A} / \mathrm{T}$ peak ratio (Fig. 4b, comparing microcosms

HD and D) seem to be favored by humic matter when Daphnia carcasses are available. However, those genera negatively correlated with these parameters are suppressed by humic matter in the presence of carcasses.

\section{Discussion}

The main objective of this study was to track the degradation of zooplankton carcasses, as a so far largely neglected but common and labile carbon source (Tang et al., 2014). Our study reveals selection of defined bacterial communities in the presence of carcasses strongly related to the specific DOM quality released from carcasses. However, carcass-induced availability of LOM and related shifts in bacterial community composition did not result in significant changes in the turnover of the added ROM pool. Consequently, our data do not support a "priming effect" (Bianchi et al., 2011) of refractory humic matter 
removal in the presence of relatively labile carbon from Daphnia carcasses. Nevertheless, the bacterial community composition was greatly affected by the presence of carcass carbon. Thus, our study adds new quantitative and qualitative data on bacterial carbon utilization related to changes in the community composition induced by changes in substrate quality, i.e. addition of zooplankton carcasses, and adds new insights in microbial-organic matter interactions.

\section{Bacterial community composition depending on carbon source}

As outlined above, we did not measure any quantitative changes in organic matter degradation between HD microcosms and the predicted values calculated based on the parameters of single-carbon source microcosms $\mathbf{H}$ and $\mathbf{D}$. Consequently, the presence of LOM from Daphnia carcasses did not change the degradation of humic matter but rather influenced the bacterial community.

According to our data on beta-diversity of bacterial assemblages (Fig. 2), the type of treatment strongly affected the bacterial community composition in each microcosm. In microcosms with no extra organic matter addition (B), the bacterial community remained similar to the initial inoculum indicating that experimental changes in environmental conditions did not modify the bacterial community composition drastically (Fig. 2). Overall, the addition of carcass LOM was the main driver of the bacterial community composition in the $\mathbf{D}$ and $\mathbf{H D}$ microcosms (Fig. 2). Bacterial taxa introduced into the microcosms with the carcasses may also have an effect on bacterial community composition and richness. However, according to literature data, zooplankton carcasses are not primarily decomposed by their native-associated bacterial communities, but rather by ambient bacteria (Bickel and Tang, 2010). This notion is also reflected by the fact that bacteria richness is the lowest in the HD and $\mathbf{D}$ treatments. Thus, in natural waters with a high amount of dead zooplankton, carcasses can be a primary factor driving bacterioplankton community composition with 
222 potential effects for carbon cycling. In many lakes with an "inverted" biomass pyramid, 223 zooplankton biomass is higher than phytoplankton biomass (Heathcote et al., 2016). We

224 suppose that the same pattern for dead biomass would indicate that zooplankton and not algal LOM, which is usually in the researcher's focus (Hoikkala et al., 2016; Landa et al., 2016), could be the major driver for bacterioplankton community composition in such ecosystems. In lakes with a "normal" biomass pyramid, zooplankton may still play an important role for determining bacterial community composition in the occasional events of mass zooplankton mortality (Tang et al., 2014). It would be interesting to test this presupposition in further studies. The co-presence of ROM also contributed to specific bacterial communities by selecting for a number of specific OTUs. The observed, significant difference in bacterial community composition between all treatments points to a pronounced effect of substrate quality on bacterial community composition and might result in functional differences.

The prevalence of Betaproteobacteria in the initial inoculum and in microcosms $\mathbf{B}$ and H (Fig. 1) was in accordance with previous studies on Lake Grosse Fuchskuhle (Grossart et al., 2008; Hutalle-Schmelzer et al., 2010). Indeed, Betaproteobacteria are among the most numerous bacteria in the upper layers of freshwater lakes, in particular of peat bog lakes (Newton et al., 2011). Moreover, the dominance of Gammaproteobacteria in carcassamended microcosms (Fig. 1) was also expected according to previous studies (Tang et al., 2009; Shoemaker and Moisander, 2015). Gammaproteobacteria include many species with a copiotrophic lifestyle that can grow faster than the average lake bacterioplankton, especially under nutrient-rich conditions as can be found on carcasses (Newton et al., 2011). Interestingly, a more distinct community pattern emerged in the different microcosms when taking the level of individual OTUs into account. This indicates a close relationship between organic carbon quality and bacterial community structure (Attermeyer et al., 2014, 2015). 


\section{Links between organic matter quality and microbial community composition}

A number of uncultivated bacterial taxa belonging to the order Sphingobacteriales were positively selected solely in the presence of carcasses only (Fig. 4a). Many members of Sphingobacteriales express chitinolytic activity (Kämpfer, 2015), but no information is available in particular about the ecological role of the uncultivated representatives found in the present study. High abundances of the NS11-12 marine group were previously associated with an increase in chlorophyll $a$ concentration (Meziti et al., 2015) and number of particles, while it is negatively correlated with nitrate concentration (Henson et al., 2016). Moreover, the uncultured bacterial group OPS 17 was previously found not to respond to terrestrial DOM additions (Lindh et al., 2015).

Another group of bacteria favored by zooplankton carcass LOM were ubiquitous chemoorganotrophs belonging to genera Brevundimonas and Aeromonas (Segers et al., 1994). Among the bacteria favored by humic matter (Fig. 4b), genera involved in nitrogen fixation (Bradyrhizobium, Rhizobacter, unclassified Rhizobiales) (Kuykendall, 2005; Goto, 2015), organic pollutants degraders Rhodococcus (Bell et al., 1998), unclassified Sphingomonadales and methylotrophs (uncultured strain PRD01a011B from Methylophilaceae (Doronina et al., 2014)) were detected. To a large extent the same bacterial genera were favored by humic matter regardless whether zooplankton carcasses were present. In contrast, bacteria suppressed by humic matter in the presence of carcasses were almost exclusively chemoorganotrophic generalists (Johansen et al., 2005; O’Sullivan et al., 2005; Song et al., 2008; McBride, 2014; Evtushenko, 2015).

Besides selecting for certain bacterial populations, zooplankton carcasses strongly decreased the species richness and evenness of the bacterial community (Table 2). Therefore it appears that the availability of a high quality and abundant LOM source can reduce the biodiversity by favoring a small number of copiotrophs dominating the community: in the 
271 present study about half of all sequences in the HD and $\mathbf{D}$ microcosms belonged to a single

272 OTU (OTU 1, Pseudomonas sp.). In a similar study of Blanchet et al. (2017), the bacterial 273 diversity was not affected by amino acid additions, possibly because free amino acids are simple compounds which can be consumed simultaneously by many members of the community (Trusova et al., 2012). Thus, this pattern can be best explained by the fact that zooplankton carcasses provide microbial habitats and complex, yet labile carbon sources shifting the overall bacterial community towards a less diverse, more uneven, and more copiotrophic community.

\section{Microbial carcass decomposition in relation to carbon quality}

An abrupt increase of LOM availability following mass zooplankton mortality commonly observed in natural waters (reviewed by Tang et al. 2014), leads to a substantial input of both DOC and POC. In agreement with a previous study (Tang et al., 2006) Daphnia carcasses lost their mostly labile internal tissues rapidly, whereas the chitin-based carapace was more resistant to dissolution and microbial decomposition (Fig S2).

However, in our study the leached fraction was rapidly consumed by numerous ambient bacteria (Table 1), and did not increase the DOC concentration significantly in the microcosms with zooplankton carcasses (D and HD). This statement is supported by our observation that adding $1.334 \pm 0.038 \mathrm{mg} \mathrm{C} \mathrm{L}^{-1}$ with Daphnia carcasses resulted in only 0.055 \pm 0.011 and $0.065 \pm 0.010 \mathrm{mg} \mathrm{C} \mathrm{L}^{-1}$ of carcasses-derived DOC in $\mathbf{D}$ and $\mathbf{H D}$ microcosms, respectively (Fig. 3).

On the other hand, the chitin-based structure of the carapace was only partially degraded and also used a surface for attachment. At the end of the experiment, $0.270 \pm 0.014$ and $0.258 \pm 0.007 \mathrm{mg} \mathrm{C} \mathrm{L} \mathrm{L}^{-1}$ originating from Daphnia carcasses $(19-20 \%$ of the initial quantity) remained in the POC fraction of the D and HD microcosms, respectively (Fig. 3), mainly represented by the remaining carapace and the bacterial biomass (Fig. S2). This is 
further confirmed by the finding that bacterial taxa degrading chitin were greatly favored in the presence of carcasses at the end of the incubation (Fig. 4). The difference between noncarcass-derived POC in microcosms $\mathbf{D}$ and $\mathbf{H D}\left(0.059 \pm 0.003\right.$ and $0.096 \pm 0.003 \mathrm{mg} \mathrm{L}^{-1}$, respectively; Fig. 3) presumably occur due to humic matter aggregation converting DOC into POC. This assumption is supported by a two-fold POC increase in the $\mathbf{H}$ microcosms compared to the initial value (Table 1).

In our experiment we used 40 Daphnia carcasses per liter, a high but still natural value (Dubovskaya et al., 2003). Most of the organic carbon originating from carcasses was respired by the bacterial community within the two weeks of incubation. Therefore, in natural systems, the considerable amount of LOM released by zooplankton carcasses (Tang et al., 2014), can directly affect the functioning of the ecosystem by accelerating microbial carbon turnover and respiratory carbon losses to the atmosphere at short time scales. The more recalcitrant part of the carapace may persist for a longer time, and eventually escapes the water column to be further processed in the sediments (Tang et al., 2014), being also important for carbon sequestration. Consequently, the balance between microbial degradation of zooplankton carcasses and organic matter storage in sediments has a great influence on the aquatic carbon cycle.

\section{Priming, a concept under debate in aquatic sciences}

Humic matter was chosen as a recalcitrant carbon source for its ubiquity in aquatic ecosystems and as an important part of the carbon pool in the global carbon cycle. Humic matter can represent up to $80 \%$ of the total DOM in freshwaters (Rocker et al., 2012a). Although humic matter is considered as recalcitrant, it can at least partially be decomposed by bacteria (Hutalle-Schmelzer et al., 2010; Rocker et al., 2012a; Kisand et al., 2013). Furthermore, the degradation of humic acids by marine and estuarine bacterial communities seems to be favored by specific environmental conditions, e.g. along a salinity gradient 
(Rocker et al., 2012a; Rocker et al., 2012b; Kisand et al., 2013). Consequently, recalcitrance and lability of organic matter are not per se intrinsic chemical characteristics (Schmidt et al., 2011), and may only account for specific environmental settings (Bianchi et al., 2015).

In our experiment, we incubated Daphnia carcasses and humic matter in different combinations to test for a priming effect of bacterial degradation of ROM induced by the addition of carcass LOM. The addition of a mixture of natural humic matter and Daphnia carcasses resulted in the degradation of organic matter and an isotopic ratio of the respired $\mathrm{CO}_{2}$ similar to what we predicted based on our linear addition model with humic matter or carcasses as the sole carbon source. Moreover, based on DOM characterization (Table 1), the natural humic matter from Lake Grosse Fuchskuhle was only little degraded by bacteria, irrespective of LOM addition via Daphnia carcasses. Consequently, and in agreement with previous studies (Bengtsson et al., 2014; Catalán et al., 2015; Dorado-García et al., 2015), we could not detect any quantitative changes in bacterial ROM degradation when using carcass LOM as a potential primer (Table 1).

Recently, a number of studies have investigated the prevalence of a priming effect in aquatic ecosystems (e.g., van Nugteren et al., 2009; Guenet et al., 2013; Kuehn et al., 2014; Steen et al., 2015). Various types of ecosystems (marine, lentic, lotic) and habitats (pelagic, hyporheic, sediments) have been tested, as well as different sources of LOM (carbohydrates, algae leachate, gastropod mucus, etc.) and ROM (terrestrial plant tissues, lignocellulose, humic matter, etc.) have been used. Although some authors have found support for ROM priming by more labile organic matter, mainly of algal origin (van Nugteren et al., 2009; Guenet et al., 2013; Hotchkiss et al., 2014; Bianchi et al., 2015; Gontikaki et al., 2015), others did not reveal any evidence for a positive priming effect (Bengtsson et al., 2014; Catalán et al., 2015; Dorado-García et al., 2015; Blanchet et al., 2017), or even found a negative priming effect (Gontikaki et al., 2013) with ROM being decomposed slower in the presence of a labile carbon source. Thus, it appears that the absence or presence of the 
347 priming effect may strongly depend on specific environmental or experimental conditions, 348 which may also explain the absence of humic matter degradation in our HD treatments using 349 Daphnia carcasses LOM as the primer.

350

351

352

\section{Limitations and applications of the study}

The degradation of ROM (such as humic matter) is a combination of two main processes: microbial and photochemical decomposition (Amado et al., 2015). The most efficient humic matter microbial degraders in aquatic systems are fungi (Grinhut et al., 2007). Generally, fungi have a higher capacity then bacteria to synthesize the extracellular oxidative enzymes involved in ROM degradation and thus more readily and successfully initiate humic matter degradation (Rojas-Jimenez et al., 2017). In contrast, bacteria join the process later as degraders of humic matter metabolites (Grossart and Rojas-Jimenez, 2016; Rojas-Jimenez et al., 2017). Due to our pre-filtration step to avoid the presence of protozoan grazers and large phytoplankton as has been frequently done in similar incubation experiments (Fonte et al., 2013; Guenet et al., 2013; Attermeyer et al., 2014, 2015; Blanchet et al., 2015), fungi, which could potentially constitute an important component of the aquatic priming effect, were removed.

Photochemical degradation can break down/oxidise recalcitrant DOM compounds, such as fulvic and humic substances, into more labile molecules (Spencer et al., 2009; Stubbins et al., 2010). It is likely that in natural systems photochemical and microbial degradation work synergistically and thus contribute to the priming effect. On the other hand, UV radiation can also affect biodegradability of LOM in the presence of humic matter (Tranvik and Kokalj, 1998). Our study was conducted in the dark as in other priming effect studies (e.g. Bianchi et al., 2015; Catalán et al., 2015) to avoid photosynthesis which could have obstructed the detection of differences in carbon oxidation between treatments and controls. Thus, it is clear that photodegradation of humic substances was not taken into 
account in the present study and might have reduced our possibilities to measure a positive priming effect. However, our study is directly applicable to the situation when the zooplankton carcasses are sinking into the pelagic zone at depths with very low light penetration.

The incubation temperature in our experiment was relatively high $\left(20^{\circ} \mathrm{C}\right)$ and not typical for deep waters. Nevertheless, if temperature might have a strong influence on bacterial community composition and its activity (Adams et al., 2010), a lower temperature only slows down the degradation process but not the biodegradability of carcasses. Therefore, in natural systems, the potential of zooplankton carcasses to release a consequential amount of carbon in the atmosphere and to select for specific bacterial community might happen over longer time scales than the ones observed in our experiment.

Another factor that can affect DOM degradation is the oxygen concentration, which usually decreases sharply with depth in the pelagic zone of humic lakes. In our experimental microcosms we maintained $100 \%$ oxygen saturation due to mixing with headspace air. However, Tang et al. (2006) observed only a small difference between microbial communities decomposing carcasses in anaerobic vs. aerobic conditions, presumably because zooplankton carcasses represent anoxic microenvironments even when oxygen is abundant in the surrounding waters (Glud et al., 2015).

Although the experimental set-up might have its limitations, our findings are relevant to natural environments such as the metalimnion of humic lakes and other deep water layers where the maximum percentage of dead zooplankton is found (Dubovskaya et al., 2018).

\section{Conclusions}

We observed a pronounced change in bacterial community composition in microcosms induced by the addition of Daphnia carcasses and humic matter. While the quality of both 
added carbon sources played a role, zooplankton carcasses were the major driver of bacterial community assembly. Even though no priming effect was detected, it is critical to continue studies on ROM degradation in the presence of zooplankton carcasses to better understand microbial dynamics and thus potential changes in organic matter fluxes in freshwater ecosystems. In events of mass zooplankton mortality, the water column can be loaded with a considerable amount of carcass-derived LOM. By decreasing the bacterial diversity and selecting specialized bacteria, zooplankton carcasses potentially have further and so far likely unknown consequences on microbial dynamics and carbon fluxes. Indeed, our results suggest that a significant part of zooplankton carcasses is respired by bacteria. Therefore, our study provides evidence that quantifying the implication of zooplankton carcasses in the functioning of aquatic ecosystems is of primordial importance to understand the amount of carbon produced in and released from freshwaters.

\section{Experimental Procedures}

\section{Experimental setup}

The experiment was conducted in laboratory microcosms, which were set up in 1L acid-washed and muffled $\left(4 \mathrm{~h}, 450{ }^{\circ} \mathrm{C}\right)$ glass bottles half-filled with artificial lake water. The microcosms were inoculated with a concentrated bacterial community from the acidic bog

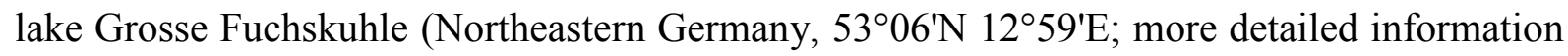
is provided in the Supplementary Methods). Microcosms were sealed with PTFE-coated silicone septa, placed on a roller apparatus (Wheaton, USA), and incubated for 15 days in the dark at $20^{\circ} \mathrm{C}$. The duration of the experiment, irradiance, temperature, and the rolling mode were chosen to fall within the range of natural conditions of sinking zooplankton carcasses in a water column (Tang et al., 2009, 2014). 
One set of microcosms (HD) was amended with humic matter and ${ }^{13} \mathrm{C}$-labeled Daphnia carcasses (Fig. S1). The detailed description of the amendments including their preparation is available in the Supplementary Methods. Carcasses control microcosms (D) were amended solely with ${ }^{13} \mathrm{C}$-labeled Daphnia carcasses in the same quantity and from the same batch of Daphnia as in HD microcosms. Humic matter control microcosms (H) were amended with humic matter only in the same quantity as in HD microcosms (Fig. S1). Further, blank microcosms (B) with no added organic matter were included to determine whether the bacterial community was capable of growing without the extra addition of organic carbon (Fig. S1). Each experimental treatment was conducted in five replicates.

\section{Bacterial counts and community composition}

Microbial abundances were determined after filtration of $5 \mathrm{~mL}$ of water through Nucleopore track-etched membrane filters with a pore size of $0.2 \mu \mathrm{m}$ (Whatman, UK). Then, samples were stained with 4',6-diamidino-2-phenylindole (DAPI) to monitor cell numbers using an imaging system linked to a Leica epifluorescence microscope. Pictures were taken from 30-50 fields and abundances were determined using the CellC software (Tampere University of Technology, Finland, https://sites.google.com/site/cellcsoftware/).

For DNA extraction, $150 \mathrm{~mL}$ of water was filtered through $0.22 \mu \mathrm{m}$ GVWP filters (Millipore, Germany) and total DNA was extracted according to a modified protocol described by Nercessian et al. (2005) (see Supplementary Methods for details). DNA concentrations were determined with a Quantus fluorometer (Promega, USA), following the manufacturer's instructions. PCR, library preparation and sequencing was done by LGC Genomics (Berlin, Germany). Briefly, the V3-V4 region was amplified using primers 341F785R (Klindworth et al., 2013), followed by library preparation (2x300 bp) and sequencing on a MiSeq Illumina platform. Sequences were quality checked and analyzed using Mothur v1.37.6 (Schloss et al., 2009), see Supplementary Methods for the detailed workflow. The 
444

445

446

447

448

449

450

451

452

453

454

455

456

457

458

459

460

461

462

463

464

465

466

sequence data was deposited in Genbank under the following accession number: PRJNA418906.

\section{Organic carbon concentration and composition}

Directly after sampling, water was passed through pre-combusted $\left(4 \mathrm{~h}, 450^{\circ} \mathrm{C}\right) \mathrm{GF} 75$ filters (Advantec, nominal pore size of $0.3 \mu \mathrm{m}$ ). Particulate organic carbon (POC) collected on the filters was measured with an Eltra SC 800 (Eltra, Germany). One subsample of filtrate was processed directly to measure the DOC concentration with a TOC-V $\mathrm{CPH}_{\mathrm{CPH}}$ (Shimadzu, Kyoto, Japan) as well as the phosphate concentration using a FIAstar 5000 (Foss, USA). Total organic carbon (TOC) concentration was estimated by summing up the DOC and POC concentrations.

Another subsample of filtrate was stored at $4^{\circ} \mathrm{C}$ for three weeks prior analysis with liquid chromatography - organic carbon detection - organic nitrogen detection (LC-OCDOND, DOC Labor, Germany). The LC-OCD-OND allows distinguishing between HMWS, LMWS, and humic substances (Huber et al., 2011). Nevertheless, its sensitivity is not sufficient for analyzing samples with low DOC concentration $\left(<0.2 \mathrm{mg} \mathrm{L}^{-1}\right)$. That was the case for the $\mathrm{D}$ and $\mathrm{B}$ microcosms which were therefore not analyzed by LC-OCD-OND.

\section{Spectral characteristics of DOM}

DOM optical characteristics were obtained with a UV-Vis spectrophotometer (Hitachi U2900, Germany) and a spectrofluorometer (Hitachi F7000, Germany). Absorbance spectra were recorded from 190 to $800 \mathrm{~nm}$ with an increment of $1 \mathrm{~nm}$ and used to compute the specific ultraviolet absorbance at $254 \mathrm{~nm}\left(\mathrm{SUVA}_{254}\right)$ and absorption spectral slopes (Weishaar et al., 2003; Helms et al., 2008). SUVA 254 is an indicator of aromaticity and chemical reactivity while the absorption slopes are used as proxies for DOM molecular weight. 
Excitation emission matrices (EEMs) were generated with excitation wavelengths ranging from 220 to $450 \mathrm{~nm}$ and emission wavelengths ranging from 230 to $600 \mathrm{~nm}$, both with $5 \mathrm{~nm}$ increments. EEMs were corrected with a MilliQ water sample and for inner filter effect using the absorbance-based method (Christmann et al., 1980; Murphy et al., 2013). Then, fluorescence, humification and freshness indices, as well as specific fluorescence intensity at various peaks were calculated as described by Hansen et al. (2016).

\section{Carbon stable isotope ratio}

Stable isotope analysis of the respired $\mathrm{CO}_{2}$ provides information on carbon substrates metabolized by the microbial community (Fabian et al., 2017). The ratio of ${ }^{13} \mathrm{C} /{ }^{12} \mathrm{C}$ in the dissolved $\mathrm{CO}_{2}$ was measured directly in each microcosm by a membrane-inlet massspectrometer dissolved gas analyzer (HiCube pumping station, Pfeiffer Vacuum and Bay Instruments membrane, USA), controlled by Quickdata software. The sampling capillary was inserted through the PTFE-coated silicone septa prior to opening microcosms in order to avoid gas leakages. Concentrations of ${ }^{12} \mathrm{CO}_{2}$ and ${ }^{13} \mathrm{CO}_{2}$ were obtained from the ion currents sequentially recorded at mass to charge $(\mathrm{m} / \mathrm{z})$ ratios of 44 and 45 , respectively.

For the carbon stable isotope ratio in POC and DOC, $100 \mathrm{ml}$ of water was passed through GF75 filters (Advantec, USA) and both the flow-through and the filter (all five replicates were pooled onto one filter to have enough material for subsequent analyzes) were collected and freeze-dried. Moreover, we dried $1 \mathrm{mg}$ of acid-killed Daphnia and approximately $1 \mathrm{mg}$ of extracted humic matter for carbon stable isotope ratio analysis. The samples were analyzed with an Elemental Analyzer (Thermo Flash EA 2000), coupled to a continuous-flow isotope ratio mass spectrometer (Thermo Finnigan Delta V) via an open split interface (Thermo Finnigan Conflow IV) in the IRMS Laboratory of the Leibniz Institute for Baltic Sea Research Warnemünde (Germany), and with a PDZ Europa ANCA-GSL elemental 
analyzer interfaced to a PDZ Europa 20-20 isotope ratio mass spectrometer (Sercon Ltd., Cheshire, UK) at the UC Davis Stable Isotope Facility (USA).

\section{Decomposition calculations}

To test for a possible priming effect, we used an addition model as in Hannides and Aller (2016). Initial and final total organic carbon concentrations in the humic control, i.e. $\mathrm{TOC}_{\mathrm{i}}(\mathrm{H})$ and $\mathrm{TOC}_{\mathrm{f}}(\mathrm{H})$, respectively, in the carcass control, i.e. $\mathrm{TOC}_{\mathrm{i}}(\mathrm{D})$ and $\mathrm{TOC}_{\mathrm{f}}(\mathrm{D})$, and in the blank, i.e. $\mathrm{TOC}_{\mathrm{i}}(\mathrm{B})$ and $\mathrm{TOC}_{\mathrm{f}}(\mathrm{B})$, respectively, were used to predict the degradation of total organic carbon $(\triangle \mathrm{TOC})$ in the HD microcosm. Thereby, we assumed that the degradation rates of carbon sources observed in the control microcosms are conserved when humic matter and carcasses are incubated together. The predicted $\Delta \mathrm{TOC}(\mathrm{H}+\mathrm{D})$ was compared with the measured $\triangle \mathrm{TOC}(\mathrm{HD})$ to detect any enhanced degradation of organic carbon caused by a potential "priming effect". Similarly, data on $\mathrm{CO}_{2}$ concentration and isotope ratio $\left({ }^{13} \mathrm{CO}_{2} /{ }^{12} \mathrm{CO}_{2}\right)$ in the microcosms was used to calculate respiration of recalcitrant and labile carbon pools. We assumed that if a priming effect is present, there should be a difference in the observed isotope ratio between measured and predicted $\mathrm{CO}_{2}$, based on the sum of control values.

The carcass carbon fraction $\left(\mathrm{F}_{\mathrm{c}}\right)$ in $\mathrm{DOC}, \mathrm{POC}$ and $\mathrm{CO}_{2}$ was calculated via a stable isotope mixing model (Hopkins and Ferguson, 2012). We also applied Keeling plot analyses of dissolved $\mathrm{CO}_{2}$ (Pataki et al., 2003) to estimate the $\delta^{13} \mathrm{C}$ of the carbon source respired in the respective microcosms. Descriptive calculation formulas are available in the Supplementary Methods.

\section{Statistical analyses}

For alpha-diversity calculations of bacterial communities, individual samples were rarefied to the lowest number of reads in a sample (10080), with 10 iterations per sample 
515

516

517

518

using QIIME (Caporaso et al., 2010). Shannon biodiversity index was calculated to estimate richness and evenness of the microcosm communities. Beta-diversity of bacterial communities was calculated by using the Bray-Curtis similarity coefficients (Bray and Curtis, 1957) using QIIME.

All analyses described below were run via $\mathrm{R}$ version 3.3.3 ( $\mathrm{R}$ Development Core Team, 2006). R package vegan (vegan: Community Ecology Package, 2017, https://CRAN.Rproject.org/package=vegan $)$ was used to carry out principal coordinate analysis $(\mathrm{PCoA})$ and to calculate ANOSIM and SIMPER (Clarke, 1993).

Bacterial community composition was linked to DOC characteristics which significantly differentiated microcosms. We used the least absolute shrinkage and selection operator (LASSO) to select genera that were influenced by a variation in DOM composition (Traving et al., 2016). Before designing the LASSO models, we summed the abundances of OTUs belonging to the same genus and performed a centered log-ratio transformation (Gloor and Reid, 2016) of the absolute abundances of all genera. To visualize the outcome, we depicted the selected genera in two different networks using Cytoscape software (Shannon et al., 2003).

All differences between treatments were tested using a one-way analysis of variance (ANOVA) and post-hoc Tukey tests. Pairwise comparisons between initial and final parameters of microcosms and between two treatments were done using Student's t-test and Wilcoxon rank sum test. Normality was checked by Shapiro-Wilks tests when necessary.

\section{Acknowledgements}

This research was funded by German Science Foundation (GR 1540/29-1, GR1549/23-1) and the Russian Foundation for Basic Research (No. 16-54-12048), and partly supported by Russian Federal Tasks of Fundamental Research (project No. 51.1.1) and by the Council on grants from the President of the Russian Federation for support of Leading 
540 Scientific Schools (grant NSh-9249.2016.5). OVK was supported by Michail-Lomonosov-

541 Programme-Linie A, 2015 (57180771) funded by the Ministry of Education and Science of 542 the Russian Federation and the German Academic Exchange Service (DAAD). The authors 543 thank Uta Mallok for DOC and phosphate concentration measurements. We are grateful to 544 Maren Voss and Iris Liskow in the IRMS Laboratory of the Leibniz Institute for Baltic Sea 545 Research Warnemünde (Germany) for stable isotope analysis. We greatly appreciate the useful advices of Jenny Fabian and Isabell Klawonn on stable isotope sample preparation and 547 data handling. We thank two anonymous reviewers for carefully reading the manuscript and 548 suggesting substantial improvements. The authors declare no conflict of interests.

\section{References}

Adams, H.E., Crump, B.C., and Kling, G.W. (2010) Temperature controls on aquatic bacterial production and community dynamics in arctic lakes and streams. Environ Microbiol 12: 1319-1333.

Amado, A.M., Cotner, J.B., Cory, R.M., Edhlund, B.L., and McNeill, K. (2015) Disentangling the interactions between photochemical and bacterial degradation of dissolved organic matter: amino acids play a central role. Microb Ecol 69: 554-566.

Attermeyer, K., Hornick, T., Kayler, Z.E., Bahr, A., Zwirnmann, E., Grossart, H.-P., and Premke, K. (2014) Enhanced bacterial decomposition with increasing addition of autochthonous to allochthonous carbon without any effect on bacterial community composition. Biogeosciences 11: 1479-1489.

Attermeyer, K., Tittel, J., Allgaier, M., Frindte, K., Wurzbacher, C., Hilt, S., et al. (2015) Effects of light and autochthonous carbon additions on microbial turnover of allochthonous organic carbon and community composition. Microb Ecol 69: 361-371. 
Battin, T.J., Luyssaert, S., Kaplan, L.A., Aufdenkampe, A.K., Richter, A., and Tranvik, L.J. (2009) The boundless carbon cycle. Nat Geosci 2: 598-600.

Bell, K.S., Philp, J.C., Aw, D.W.J., and Christofi, N. (1998) The genus Rhodococcus. J Appl Microbiol 85: 195-210.

Bengtsson, M.M., Wagner, K., Burns, N.R., Herberg, E.R., Wanek, W., Kaplan, L.A., and Battin, T.J. (2014) No evidence of aquatic priming effects in hyporheic zone microcosms. Sci Rep 4: 5187.

Bianchi, T.S. (2011) The role of terrestrially derived organic carbon in the coastal ocean: A changing paradigm and the priming effect. Proc Natl Acad Sci 108: 19473-19481.

Bianchi, T.S., Thornton, D.C.O., Yvon-Lewis, S.A., King, G.M., Eglinton, T.I., Shields, M.R., et al. (2015) Positive priming of terrestrially derived dissolved organic matter in a freshwater microcosm system. Geophys Res Lett 42: 5460-5467.

Bickel, S.L., and Tang, K.W. (2010) Microbial decomposition of proteins and lipids in copepod versus rotifer carcasses. Mar Biol 157: 1613-1624.

Blanchet, M., Pringault, O., Bouvy, M., Catala, P., Oriol, L., Caparros, J., et al. (2015) Changes in bacterial community metabolism and composition during the degradation of dissolved organic matter from the jellyfish Aurelia aurita in a Mediterranean coastal lagoon. Environ Sci Pollut Res 22: 13638-13653.

Blanchet, M., Pringault, O., Panagiotopoulos, C., Lefevre, D., Charriere, B., Ghiglione, J.-F., et al. (2017) When riverine dissolved organic matter (DOM) meets labile DOM in coastal waters: changes in bacterial community activity and composition. Aquat Sci 79: $27-43$.

Bray, J.R., and Curtis, J.T. (1957) An ordination of the upland forest communities of Southern Wisconsin. Ecol Monogr 27: 325-349. 
Caporaso, J.G., Kuczynski, J., Stombaugh, J., Bittinger, K., Bushman, F.D., Costello, E.K., et al. (2010) QIIME allows analysis of high-throughput community sequencing data. Nat Methods 7: 335-336.

Catalán, N., Kellerman, A.M., Peter, H., Carmona, F., and Tranvik, L.J. (2015) Absence of a priming effect on dissolved organic carbon degradation in lake water. Limnol Oceanogr 60: 159-168.

Christmann, D.R., Crouch, S.R., Holland, J.F., and Timnick, A. (1980) Correction of rightangle molecular fluorescence measurements for absorption of fluorescence radiation. Anal Chem 52: 291-295.

Clarke, K.R. (1993) Non-parametric multivariate analyses of changes in community structure. Austral Ecol 18: 117-143.

Dorado-García, I., Syväranta, J., Devlin, S.P., Medina-Sánchez, J.M., and Jones, R.I. (2015) Experimental assessment of a possible microbial priming effect in a humic boreal lake. Aquat Sci 1-12.

Doronina, N., Kaparullina, E., and Trotsenko, Y. (2014) The Family Methylophilaceae. In Rosenberg, E., DeLong, E.F., Lory, S., Stackebrandt, E., and Thompson, F. (eds), The Prokaryotes: Alphaproteobacteria and Betaproteobacteria. Springer Berlin Heidelberg, Berlin, Heidelberg, pp. 869-880.

Dubovskaya, O.P., Gladyshev, M.I., Gubanov, V.G., and Makhutova, O.N. (2003) Study of non-consumptive mortality of Crustacean zooplankton in a Siberian reservoir using staining for live/dead sorting and sediment traps. Hydrobiologia 504: 223-227.

Dubovskaya, O.P., Tolomeev, A.P., Kirillin, G., Buseva, Z., Tang, K.W., and Gladyshev, M.I. (2018) Effects of water column processes on the use of sediment traps to measure zooplankton non-predatory mortality: a mathematical and empirical assessment. $J$ Plankton Res 40: 91-106. 
613 Elliott, D.T., Harris, C.K., and Tang, K.W. (2010) Dead in the water: The fate of copepod

614

615

616

617

618

619

620

621

622

623

624

625

626

627

628

629

630

631

632

633

634

635

636

637 carcasses in the York River estuary, Virginia. Limnol Oceanogr 55: 1821-1834.

Evtushenko, L.I. (2015) Marmoricola. In Bergey's Manual of Systematics of Archaea and Bacteria. John Wiley \& Sons, Ltd.

Fabian, J., Zlatanovic, S., Mutz, M., and Premke, K. (2017) Fungal-bacterial dynamics and their contribution to terrigenous carbon turnover in relation to organic matter quality. ISME J 11: 415-425.

Fonte, E.S., Amado, A.M., Meirelles-Pereira, F., Esteves, F.A., Rosado, A.S., and Farjalla, V.F. (2013) The combination of different carbon sources enhances bacterial growth efficiency in aquatic ecosystems. Microb Ecol 66: 871-878.

Gloor, G.B., and Reid, G. (2016) Compositional analysis: a valid approach to analyze microbiome high-throughput sequencing data. Can J Microbiol 62: 692-703.

Glud, R.N., Grossart, H.-P., Larsen, M., Tang, K.W., Arendt, K.E., Rysgaard, S., et al. (2015) Copepod carcasses as microbial hot spots for pelagic denitrification. Limnol Oceanogr 60: 2026-2036.

Gómez-Consarnau, L., Lindh, M.V., Gasol, J.M., and Pinhassi, J. (2012) Structuring of bacterioplankton communities by specific dissolved organic carbon compounds. Environ Microbiol 14: 2361-2378.

Gontikaki, E., Thornton, B., Huvenne, V.A.I., and Witte, U. (2013) Negative priming effect on organic matter mineralisation in NE Atlantic slope sediments. PLoS ONE 8: e67722.

Gontikaki, E., Thornton, B., Cornulier, T., and Witte, U. (2015) Occurrence of priming in the degradation of lignocellulose in marine sediments. PLOS ONE 10: e0143917.

Goto, M. (2015) Rhizobacter. In, Bergey's Manual of Systematics of Archaea and Bacteria. John Wiley \& Sons, Ltd. 
638 Grinhut, T., Hadar, Y., and Chen, Y. (2007) Degradation and transformation of humic

639

640

641

642

643

644

645

646

647

648

649

650

651

652

653

654

655

656

657

658

659

660

661

662

663 substances by saprotrophic fungi: processes and mechanisms. Fungal Biol Rev. 21: 179-189.

Grossart, H.-P. (2010) Ecological consequences of bacterioplankton lifestyles: changes in concepts are needed. Environ Microbiol Rep 2: 706-714.

Grossart, H.-P. and Rojas-Jimenez, K. (2016) Aquatic fungi: targeting the forgotten in microbial ecology. Curr Opin Microbiol 31: 140-145.

Grossart, H.-P., Tang, K.W., Kiørboe, T., and Ploug, H. (2007) Comparison of cell-specific activity between free-living and attached bacteria using isolates and natural assemblages. FEMS Microbiol Lett 266: 194-200.

Grossart, H.-P., Jezbera, J., Hornak, K., Hutalle, K.M.L., Buck, U., and Simek, K. (2008) Top-down and bottom-up induced shifts in bacterial abundance, production and community composition in an experimentally divided humic lake. Environ Microbiol 10: $635-652$.

Guenet, B., Danger, M., Harrault, L., Allard, B., Jauset-Alcala, M., Bardoux, G., et al. (2013) Fast mineralization of land-born $\mathrm{C}$ in inland waters: first experimental evidences of aquatic priming effect. Hydrobiologia 721: 35-44.

Hannides, A.K. and Aller, R.C. (2016) Priming effect of benthic gastropod mucus on sedimentary organic matter remineralization. Limnol Oceanogr 61: 1640-1650.

Hansen, A.M., Kraus, T.E.C., Pellerin, B.A., Fleck, J.A., Downing, B.D., and Bergamaschi, B.A. (2016) Optical properties of dissolved organic matter (DOM): Effects of biological and photolytic degradation. Limnol Oceanogr 61: 1015-1032.

Heathcote, A., Filstrup, C., Kendall, D., and Downing, J. (2016) Biomass pyramids in lake plankton: influence of Cyanobacteria size and abundance. Inland Waters 6: 250-257.

Helms, J.R., Stubbins, A., Ritchie, J.D., Minor, E.C., Kieber, D.J., and Mopper, K. (2008) Absorption spectral slopes and slope ratios as indicators of molecular weight, source, 
664

665

666

667

668

669

670

671

672

673

674

675

676

677

678

679

680

681

682

683

684

685

686

687

688

and photobleaching of chromophoric dissolved organic matter. Limnol Oceanogr 53: 955-969.

Henson, M.W., Hanssen, J., Spooner, G., Flemming, P., Pukonen, M., Stahr, F., and Thrash, J.C. (2016) Microbial regime changes and indicators of eutrophication on the Mississippi River identified via a human-powered $2900 \mathrm{~km}$ transect. bioRxiv. doi: https://doi.org/10.1101/091512

Hoikkala, L., Tammert, H., Lignell, R., Eronen-Rasimus, E., Spilling, K., and Kisand, V. (2016) Autochthonous dissolved organic matter drives bacterial community composition during a bloom of filamentous Cyanobacteria. Front Mar Sci 3: 111.

Hopkins, J.B. and Ferguson, J.M. (2012) Estimating the diets of animals using stable isotopes and a comprehensive Bayesian mixing model. PLoS ONE 7: e28478.

Hotchkiss, E.R., Hall, R.O., Baker, M.A., Rosi-Marshall, E.J., and Tank, J.L. (2014) Modeling priming effects on microbial consumption of dissolved organic carbon in rivers. J Geophys Res Biogeosciences 119: 982-995.

Huber, S.A., Balz, A., Abert, M., and Pronk, W. (2011) Characterisation of aquatic humic and non-humic matter with size-exclusion chromatography-organic carbon detectionorganic nitrogen detection (LC-OCD-OND). Water Res 45: 879-885.

Hutalle-Schmelzer, K.M.L., Zwirnmann, E., Krüger, A., and Grossart, H.-P. (2010) Enrichment and cultivation of pelagic bacteria from a humic lake using phenol and humic matter additions. FEMS Microbiol Ecol 72: 58-73.

Johansen, J.E., Binnerup, S.J., Kroer, N., and Mølbak, L. (2005) Luteibacter rhizovicinus gen. nov., sp. nov., a yellow-pigmented gammaproteobacterium isolated from the rhizosphere of barley (Hordeum vulgare L.). Int J Syst Evol Microbiol 55: 2285-2291.

Kämpfer, P. (2015) Sphingobacteriales ord. nov. In Bergey's Manual of Systematics of Archaea and Bacteria. John Wiley \& Sons, Ltd. 
689 Kirillin, G., Grossart, H.-P., and Tang, K.W. (2012) Modeling sinking rate of zooplankton

690

691

692

693

694

695

696

697

698

699

700

701

702

703

704

705

706

707

708

709

710

711

712 carcasses: Effects of stratification and mixing. Limnol Oceanogr 57: 881-894.

Kisand, V., Gebhardt, S., Rullkötter, J., and Simon, M. (2013) Significant bacterial transformation of riverine humic matter detected by pyrolysis GC-MS in serial chemostat experiments. Mar Chem 149: 23-31.

Klindworth, A., Pruesse, E., Schweer, T., Peplies, J., Quast, C., Horn, M., and Glöckner, F.O. (2013) Evaluation of general 16S ribosomal RNA gene PCR primers for classical and next-generation sequencing-based diversity studies. Nucleic Acids Res 41: e1.

Kuehn, K.A., Francoeur, S.N., Findlay, R.H., and Neely, R.K. (2014) Priming in the microbial landscape: periphytic algal stimulation of litter-associated microbial decomposers. Ecology 95: 749-762.

Kuykendall, L.D. (2005) Order VI. Rhizobiales ord. nov. In, Bergey's Manual of Systematics of Archaea and Bacteria. John Wiley \& Sons, Ltd.

Landa, M., Blain, S., Christaki, U., Monchy, S., and Obernosterer, I. (2016) Shifts in bacterial community composition associated with increased carbon cycling in a mosaic of phytoplankton blooms. ISME J 10: 39-50.

Lindh, M.V., Lefébure, R., Degerman, R., Lundin, D., Andersson, A., and Pinhassi, J. (2015) Consequences of increased terrestrial dissolved organic matter and temperature on bacterioplankton community composition during a Baltic Sea mesocosm experiment. AMBIO 44: 402-412.

McBride, M.J. (2014) The Family Flavobacteriaceae. In Rosenberg, E., DeLong, E.F., Lory, S., Stackebrandt, E., and Thompson, F. (eds), The Prokaryotes: other major lineages of Bacteria and the Archaea. Springer Berlin Heidelberg, Berlin, Heidelberg, pp. 643676. 
Meziti, A., Kormas, K.A., Moustaka-Gouni, M., and Karayanni, H. (2015) Spatially uniform but temporally variable bacterioplankton in a semi-enclosed coastal area. Syst Appl Microbiol 38: $358-367$.

Murphy, K.R., Stedmon, C.S., Graeber, D., and Bro, R. (2013) Fluorescence spectroscopy and multi-way techniques. PARAFAC. Anal Methods 5: 6557-6566.

Nercessian, O., Noyes, E., Kalyuzhnaya, M.G., Lidstrom, M.E., and Chistoserdova, L. (2005) Bacterial populations active in metabolism of $\mathrm{C} 1$ compounds in the sediment of Lake Washington, a freshwater lake. Appl Environ Microbiol 71: 6885-6899.

Newton, R.J., Jones, S.E., Eiler, A., McMahon, K.D., and Bertilsson, S. (2011) A guide to the natural history of freshwater lake bacteria. Microbiol Mol Biol Rev 75: 14-49.

van Nugteren, P., Moodley, L., Brummer, G.-J., Heip, C.H.R., Herman, P.M.J., and Middelburg, J.J. (2009) Seafloor ecosystem functioning: the importance of organic matter priming. Mar Biol 156: 2277-2287.

O’Sullivan, L.A., Rinna, J., Humphreys, G., Weightman, A.J., and Fry, J.C. (2005) Fluviicola taffensis gen. nov., sp. nov., a novel freshwater bacterium of the family Cryomorphaceae in the phylum 'Bacteroidetes'. Int J Syst Evol Microbiol 55: 21892194.

Pace, M.L., Cole, J.J., Carpenter, S.R., Kitchell, J.F., Hodgson, J.R., Van de Bogert, M.C., et al. (2004) Whole-lake carbon-13 additions reveal terrestrial support of aquatic food webs. Nature 427: 240-243.

Pataki, D.E., Ehleringer, J.R., Flanagan, L.B., Yakir, D., Bowling, D.R., Still, C.J., et al. (2003) The application and interpretation of Keeling plots in terrestrial carbon cycle research. Glob Biogeochem Cycles 17: 1022.

Rocker, D., Kisand, V., Scholz-Böttcher, B., Kneib, T., Lemke, A., Rullkötter, J., and Simon, M. (2012a) Differential decomposition of humic acids by marine and estuarine bacterial communities at varying salinities. Biogeochemistry 111: 331-346. 
Rocker, D., Brinkhoff, T., Grüner, N., Dogs, M., and Simon, M. (2012b) Composition of humic acid-degrading estuarine and marine bacterial communities. FEMS Microbiol Ecol 80: 45-63.

Rojas-Jimenez, K., Fonvielle, J.A., Ma, H., and Grossart, H.-P. (2017) Transformation of humic substances by the freshwater Ascomycete Cladosporium sp. Limnol Oceanogr 62: $1955-1962$.

Schloss, P.D., Westcott, S.L., Ryabin, T., Hall, J.R., Hartmann, M., Hollister, E.B., et al. (2009) Introducing mothur: open-source, platform-independent, community-supported software for describing and comparing microbial communities. Appl Environ Microbiol 75: 7537-7541.

Schmidt, M.W.I., Torn, M.S., Abiven, S., Dittmar, T., Guggenberger, G., Janssens, I.A., et al. (2011) Persistence of soil organic matter as an ecosystem property. Nature 478: 4956.

Segers, P., Vancanneyt, M., Pot, B., Torck, U., Hoste, B., Dewettinck, D., et al. (1994) Classification of Pseudomonas diminuta Leifson and Hugh 1954 and Pseudomonas vesicularis Busing, Doll, and Freytag 1953 in Brevundimonas gen. nov. as Brevundimonas diminuta comb. nov. and Brevundimonas vesicularis comb. nov., respectively.

Shannon, P., Markiel, A., Ozier, O., Baliga, N.S., Wang, J.T., Ramage, D., et al. (2003) Cytoscape: a software environment for integrated models of biomolecular interaction networks. Genome Res 13: 2498-2504.

Shoemaker, K.M. and Moisander, P.H. (2015) Microbial diversity associated with copepods in the North Atlantic subtropical gyre. FEMS Microbiol Ecol 91: fiv064-fiv064.

Song, J., Choo, Y.-J., and Cho, J.-C. (2008) Perlucidibaca piscinae gen. nov., sp. nov., a freshwater bacterium belonging to the family Moraxellaceae. Int J Syst Evol Microbiol 58: 97-102. 
765

766

767

768

769

770

771

772

773

774

775

776

777

778

779

780

781

782

783

784

785

786

787

788

789

Spencer, R.G.M., Aiken, G.R., Butler, K.D., Dornblaser, M.M., Striegl, R.G., and Hernes, P.J. (2009) Utilizing chromophoric dissolved organic matter measurements to derive export and reactivity of dissolved organic carbon exported to the Arctic Ocean: A case study of the Yukon River, Alaska. Geophys Res Lett 36: L06401, doi: 10.1029/2008GL036831 .

Steen, A.D., Quigley, L.N.M., and Buchan, A. (2015) Evidence for the priming effect in a planktonic estuarine microbial community. Front Mar Sci 3: 6.

Steinberg, D.K. and Landry, M.R. (2017) Zooplankton and the ocean carbon cycle. Annu Rev Mar Sci 9: 413-444.

Stubbins, A., Spencer, R.G.M., Chen, H., Hatcher, P.G., Mopper, K., Hernes, P.J., et al. (2010) Illuminated darkness: Molecular signatures of Congo River dissolved organic matter and its photochemical alteration as revealed by ultrahigh precision mass spectrometry. Limnol Oceanogr 55: 1467-1477.

Tang, K.W., Hutalle, K.M.L., and Grossart, H. (2006) Microbial abundance, composition and enzymatic activity during decomposition of copepod carcasses. Aquat Microb Ecol 45 : 219-227.

Tang, K., Dziallas, C., Hutalle-Schmelzer, K., and Grossart, H.-P. (2009) Effects of food on bacterial community composition associated with the copepod Acartia tonsa Dana. Biol Lett 5: 549.

Tang, K.W., Turk, V., and Grossart, H. (2010) Linkage between crustacean zooplankton and aquatic bacteria. Aquat Microb Ecol 61: 261-277.

Tang, K.W., Gladyshev, M.I., Dubovskaya, O.P., Kirillin, G., and Grossart, H.-P. (2014) Zooplankton carcasses and non-predatory mortality in freshwater and inland sea environments. J Plankton Res 36: 597-612.

Tranvik, L.J. and Kokalj, S. (1998) Decreased biodegradability of algal DOC due to interactive effects of UV radiation and humic matter. Aquat Microb Ecol 14: 301-307. 
Tranvik, L.J., Downing, J.A., Cotner, J.B., Loiselle, S.A., Striegl, R.G., Ballatore, T.J., et al. (2009) Lakes and reservoirs as regulators of carbon cycling and climate. Limnol Oceanogr 54: 2298-2314.

Traving, S.J., Bentzon-Tilia, M., Knudsen-Leerbeck, H., Mantikci, M., Hansen, J.L.S., Stedmon, C.A., et al. (2016) Coupling bacterioplankton populations and environment to community function in coastal temperate waters. Front Microbiol 7: 1533.

Trusova, M.Y., Kolmakova, O.V., and Gladyshev, M.I. (2012) Seasonal features of consumption of lysine by uncultivated bacterial plankton of eutrophic water reservoir. Contemp Probl Ecol 5: 391-398.

Vachon, D., Prairie, Y.T., Guillemette, F., and del Giorgio, P.A. (2017) Modeling allochthonous dissolved organic carbon mineralization under variable hydrologic regimes in boreal lakes. Ecosystems 20: 781-795.

Ward, N.D., Keil, R.G., Medeiros, P.M., Brito, D.C., Cunha, A.C., Dittmar, T., et al. (2013) Degradation of terrestrially derived macromolecules in the Amazon River. Nat Geosci 6: $530-533$.

Weishaar, J.L., Aiken, G.R., Bergamaschi, B.A., Fram, M.S., Fujii, R., and Mopper, K. (2003) Evaluation of specific ultraviolet absorbance as an indicator of the chemical composition and reactivity of dissolved organic carbon. Environ Sci Technol 37: $4702-4708$.

\section{Table and Figure legends}

Table 1. Chemical and optical parameters of experimental microcosms varying in carbon sources: $\mathbf{B}_{\mathbf{i}}-$ blank initial, $\mathbf{B}_{\mathbf{f}}-$ blank final, $\mathbf{H}_{\mathbf{i}}-$ humic matter initial, $\mathbf{H}_{\mathbf{f}}-$ humic matter final, $\mathbf{D}_{\mathbf{i}}-$ carcasses initial, $\mathbf{D}_{\mathbf{f}}-$ carcasses final, $\mathbf{H D}_{\mathbf{i}}-$ humic matter + carcasses initial, $\mathbf{H D}_{\mathbf{f}}-$ humic matter + carcasses final. Parameters in $\mathbf{D}_{\mathbf{i}}$ and $\mathbf{H} \mathbf{D}_{\mathbf{i}}$ were not measured directly but calculated from parameters in $\mathbf{B}_{\mathbf{i}}$ and $\mathbf{H}_{\mathbf{i}}$. Values are given as means of five replicates \pm 
standard errors, except for the initial DNA concentration values obtained from a single measurement. $\mathrm{nd}=$ not determined.

Table 2. Alpha-diversity of bacterial communities in the microcosms with additions of humic matter (H), Daphnia carcasses (D), humic matter and carcasses together (HD), and blank with no carbon sources $(\mathbf{B})$. Values are given as means of five replicates \pm standard errors, except for the initial inoculate (I) obtained from a single measurement, and $\mathbf{B}$ microcosms (four replicates due to too low DNA content in one sample).

Table 3. Abundances (in \%) of the quantitatively prominent OTUs contributing the most to the dissimilarity among the inoculum sample (I) and the end points of the microcosms with additions of humic matter $(\mathbf{H})$, Daphnia carcasses $(\mathbf{D})$, humic matter and carcasses together (HD), and blank with no carbon sources (B). Values are given as means of five replicates \pm standard errors, except for the inoculum sample obtained from a single measurement, and $\mathbf{B}$ microcosms (four replicates due to low DNA content of two samples which were pooled).

Fig. 1 Relative abundance of major bacterial phyla and classes of Proteobacteria in the initial sample (I) and the end points of microcosms with additions of humic matter $(\mathbf{H})$, Daphnia carcasses (D), humic matter and carcasses together (HD), and blank with no carbon sources $(\mathbf{B})$.

Fig. 2 Principal coordinate analysis of the initial sample (I) and the end points of microcosms with additions of humic matter $(\mathbf{H})$, Daphnia carcasses $(\mathbf{D})$, humic matter and carcasses together (HD), and blank with no carbon sources (B), based on Bray-Curtis community similarity, calculated as relative abundance of operational taxonomic units (OTUs).

Fig. 3 Carbon fractions originated from Daphnia carcasses at the end of the experiment in pools of dissolved (DOC) and particulate organic carbon (POC) as well as in 
841 dissolved $\mathrm{CO}_{2}$ in microcosms with humic matter and Daphnia carcasses (HD) and carcasses

842 only (D). The area size of diagrams is relative to carbon concentration.

$843 \quad$ Fig. 4 Network of bacterial genera connected with major DOM parameters,

844 significantly different in pairs of microcosms: a - microcosms $\mathbf{H}$ - humic matter, and $\mathbf{D}$ -

845 carcasses; $\mathrm{b}$ - microcosms HD - humic matter + carcasses, and $\mathbf{D}$ - carcasses. Nodes that

846 interact positively are connected by solid black edges, nodes connected by dashed edges have

847 negative interactions. Legend: DOC - concentration of DOC; HIX - humification index, FIX

848 - fluorescence index, fresh - freshness index, SUVA254 - Specific UV absorbance at 254

$849 \mathrm{~nm}, \mathrm{~A} / \mathrm{T}$ - ratio between the specific fluorescence at peak A (excitation 240-260 nm/emission

$850 \quad 400-500 \mathrm{~nm}$, UVC humic-like fluorescent component) and peak T (excitation 270-285

$851 \mathrm{~nm} / \mathrm{emission}$ 340-380 nm, tryptophan-like fluorescent component). 
Table 1. Chemical and optical parameters of experimental microcosms varying in carbon sources: $\mathbf{B}_{\mathbf{i}}-$ blank initial, $\mathbf{B}_{\mathbf{f}}-$ blank final, $\mathbf{H}_{\mathbf{i}}-$ humic matter initial, $\mathbf{H}_{\mathbf{f}}-$ humic matter final, $\mathbf{D}_{\mathbf{i}}-$ carcasses initial, $\mathbf{D}_{\mathbf{f}}-$ carcasses final, $\mathbf{H D}_{\mathbf{i}}-$ humic matter + carcasses initial, $\mathbf{H D}_{\mathbf{f}}-$ humic matter + carcasses final. Parameters in $\mathbf{D}_{\mathbf{i}}$ and $\mathbf{H D}_{\mathbf{i}}$ were not measured directly but calculated from parameters in $\mathbf{B}_{\mathbf{i}}$ and $\mathbf{H}_{\mathbf{i}}$. Values are given as means of five replicates \pm standard errors, except for the initial DNA concentration values obtained from a single measurement. nd $=$ not determined.

\begin{tabular}{|c|c|c|c|c|c|c|c|c|}
\hline $\begin{array}{l}\text { Chemical } \\
\text { parameters }\end{array}$ & $\mathbf{B}_{\mathbf{i}}$ & $\mathbf{B}_{\mathrm{f}}$ & $\mathbf{H}_{\mathbf{i}}$ & $\mathbf{H}_{\mathrm{f}}$ & $\mathbf{D}_{\mathbf{i}}$ & $\mathbf{D}_{\mathrm{f}}$ & $H_{D_{i}}$ & $\mathbf{H D}_{\mathrm{f}}$ \\
\hline $\mathrm{DOC} \mathrm{mg} \cdot \mathrm{L}^{-1}$ & $0.221 \pm 0.003$ & $0.216 \pm 0.009$ & $3.025 \pm 0.070$ & $2.952 \pm 0.109$ & $0.221 \pm 0.003$ & $0.269 \pm 0.016$ & $3.025 \pm 0.070$ & $2.944 \pm 0.017$ \\
\hline $\mathrm{POC} \mathrm{mg} \cdot \mathrm{L}^{-1}$ & $0.044 \pm 0.006$ & $0.028 \pm 0.004$ & $0.033 \pm 0.002$ & $0.067 \pm 0.010$ & $1.378 \pm 0.044$ & $0.333 \pm 0.015$ & $1.367 \pm 0.040$ & $0.354 \pm 0.007$ \\
\hline $\begin{array}{l}\text { Humic substances } \\
\left(\mathrm{mg} \cdot \mathrm{L}^{-1}\right)\end{array}$ & nd & nd & $2.065 \pm 0.034$ & $2.130 \pm 0.015$ & nd & nd & $2.065 \pm 0.034$ & $2.125 \pm 0.009$ \\
\hline $\begin{array}{l}\text { Building blocks of } \\
\text { humic substances } \\
\left(\mathrm{mg} \cdot \mathrm{L}^{-1}\right)\end{array}$ & nd & nd & $0.185 \pm 0.020$ & $0.156 \pm 0.010$ & nd & nd & $0.185 \pm 0.020$ & $0.174 \pm 0.012$ \\
\hline $\begin{array}{l}\text { Low molecular- } \\
\text { weight acids }\left(\mathrm{mg} \cdot \mathrm{L}^{-1}\right)\end{array}$ & nd & nd & $0.020 \pm 0.002$ & $0.019 \pm 0.001$ & nd & nd & $0.020 \pm 0.002$ & $0.019 \pm 0.002$ \\
\hline $\begin{array}{l}\text { Amphiphylic } \\
\text { molecules }\left(\mathrm{mg} \cdot \mathrm{L}^{-1}\right)\end{array}$ & nd & nd & $0.290 \pm 0.032$ & $0.248 \pm 0.043$ & nd & nd & $0.290 \pm 0.032$ & $0.271 \pm 0.022$ \\
\hline $\begin{array}{l}\text { Polysaccharides } \\
\left(\mathrm{mg} \cdot \mathrm{L}^{-1}\right)\end{array}$ & nd & nd & $0.073 \pm 0.002$ & $0.056 \pm 0.005$ & nd & nd & $0.073 \pm 0.002$ & $0.069 \pm 0.008$ \\
\hline Phosphate $\left(\mathrm{mg} \cdot \mathrm{L}^{-1}\right)$ & $0.332 \pm 0.003$ & $0.337 \pm 0.003$ & $0.339 \pm 0.003$ & $0.323 \pm 0.002$ & $0.332 \pm 0.003$ & $0.340 \pm 0.001$ & $0.339 \pm 0.003$ & $0.329 \pm 0.002$ \\
\hline $\begin{array}{l}\text { DNA concentration } \\
\left(\mathrm{ng} \cdot \mathrm{mL}^{-1} \text { of medium }\right)\end{array}$ & 0.14 & $0.112 \pm 0.043$ & nd & $1.569 \pm 0.348$ & nd & $20.467 \pm 2.250$ & nd & $29.133 \pm 0.879$ \\
\hline $\begin{array}{l}\text { Bacterial cell count } \\
\left(10^{6} \text { cells } \cdot \mathrm{mL}^{-1}\right)\end{array}$ & $1.343 \pm 0.601$ & $1.403 \pm 0.627$ & nd & $1.931 \pm 0.864$ & nd & $10.129 \pm 4.530$ & nd & $9.630 \pm 4.307$ \\
\hline
\end{tabular}


Table 1 (continued).

\begin{tabular}{|c|c|c|c|c|c|c|}
\hline Absorbance measurements & $\mathbf{B}_{\mathbf{i}}, \mathbf{D}_{\mathbf{i}}$ & $\mathbf{B}_{\mathrm{f}}$ & $\mathbf{D}_{\mathbf{f}}$ & $\mathbf{H}_{\mathbf{i}}, \mathbf{H D}_{\mathbf{i}}$ & $\mathbf{H}_{\mathbf{f}}$ & $\mathbf{H D}_{\mathbf{f}}$ \\
\hline $\begin{array}{l}\text { Specific UV absorbance at } 254 \mathrm{~nm} \\
\left.\text { SUVA }_{254}\left(\mathrm{~L} \mathrm{mg}^{-1} \mathrm{~L}^{-1}\right)\right]\end{array}$ & $0.431 \pm 0.085$ & $0.188 \pm 0.055$ & $0.177 \pm 0.022$ & $3.826 \pm 0.030$ & $3.723 \pm 0.050$ & $3.775 \pm 0.009$ \\
\hline Spectral slope at $275-295 \mathrm{~nm}\left(\mathrm{~nm}^{-1}\right)$ & $0.015 \pm 0.000$ & $0.029 \pm 0.014$ & $0.032 \pm 0.007$ & $0.014 \pm 0.000$ & $0.013 \pm 0.000$ & $0.013 \pm 0.000$ \\
\hline Spectral slope at $350-400 \mathrm{~nm}\left(\mathrm{~nm}^{-1}\right)$ & $0.005 \pm 0.000$ & $0.003 \pm 0.001$ & $0.005 \pm 0.000$ & $0.008 \pm 0.000$ & $0.014 \pm 0.001$ & $0.013 \pm 0.001$ \\
\hline Spectral slopes ratio & $0.691 \pm 0.034$ & nd & $0.811 \pm 0.234$ & $0.765 \pm 0.008$ & $0.821 \pm 0.009$ & $0.818 \pm 0.009$ \\
\hline Fluorescence measurements & $\mathbf{B}_{\mathbf{i}}, \mathbf{D}_{\mathbf{i}}$ & $\mathbf{B}_{\mathrm{f}}$ & $\mathbf{D}_{\mathrm{f}}$ & $\mathbf{H}_{\mathrm{i}}, \mathbf{H D}_{\mathrm{i}}$ & $\mathbf{H}_{\mathbf{f}}$ & $\mathbf{H D}_{\mathbf{f}}$ \\
\hline Fluorescence index (FIX) & $1.739 \pm 0.218$ & $1.524 \pm 0.331$ & $1.501 \pm 0.073$ & $1.808 \pm 0.009$ & $1.779 \pm 0.020$ & $1.798 \pm 0.008$ \\
\hline Humification index (HIX) & $0.246 \pm 0.018$ & $0.226 \pm 0.362$ & $0.392 \pm 0.018$ & $0.887 \pm 0.002$ & $0.879 \pm 0.003$ & $0.877 \pm 0.004$ \\
\hline Freshness index $(\beta: \alpha)$ & $0.851 \pm 0.138$ & $1.231 \pm 0.196$ & $0.855 \pm 0.034$ & $0.556 \pm 0.003$ & $0.555 \pm 0.003$ & $0.550 \pm 0.015$ \\
\hline 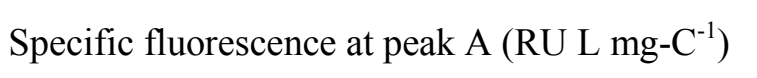 & $0.008 \pm 0.001$ & $0.010 \pm 0.002$ & $0.015 \pm 0.000$ & $0.563 \pm 0.008$ & $0.579 \pm 0.007$ & $0.574 \pm 0.008$ \\
\hline Specific fluorescence at peak B (RU L mg-C $\left.\mathrm{C}^{-1}\right)$ & $0.790 \pm 0.011$ & $0.330 \pm 0.070$ & $0.252 \pm 0.011$ & $0.808 \pm 0.037$ & $0.221 \pm 0.009$ & $0.343 \pm 0.101$ \\
\hline Specific fluorescence at peak $\mathrm{C}\left(\mathrm{RU} \mathrm{L} \mathrm{mg- \textrm {C } ^ { - 1 } )}\right.$ & $0.005 \pm 0.002$ & $0.004 \pm 0.001$ & $0.007 \pm 0.000$ & $0.253 \pm 0.004$ & $0.264 \pm 0.001$ & $0.272 \pm 0.003$ \\
\hline Specific fluorescence at peak M (RU L mg-C $\left.\mathrm{C}^{-1}\right)$ & $0.006 \pm 0.000$ & $0.008 \pm 0.001$ & $0.011 \pm 0.000$ & $0.303 \pm 0.005$ & $0.319 \pm 0.002$ & $0.338 \pm 0.007$ \\
\hline Specific fluorescence at peak T (RU L mg-C $\left.\mathrm{C}^{-1}\right)$ & $0.071 \pm 0.002$ & $0.076 \pm 0.003$ & $0.083 \pm 0.003$ & $0.136 \pm 0.003$ & $0.145 \pm 0.003$ & $0.155 \pm 0.003$ \\
\hline
\end{tabular}


Table 2. Alpha-diversity of bacterial communities in the microcosms with additions of humic matter $(\mathbf{H})$, Daphnia carcasses (D), humic matter and carcasses together (HD), and blank with no carbon sources $(\mathbf{B})$. Values are given as means of five replicates \pm standard errors, except for the initial inoculate (I) obtained from a single measurement, and $\mathbf{B}$ microcosms (four replicates due to low DNA content in one sample).

\begin{tabular}{|l|ccc|ccc|}
\hline Microcosm & \multicolumn{3}{|c|}{ Observed OTUs } & \multicolumn{3}{|c|}{ Shannon Index } \\
\hline I & \multicolumn{3}{|c|}{313.4} & \multicolumn{3}{c|}{5.00} \\
\hline B & 234.0 & \pm & 13.1 & 4.60 & \pm & 0.27 \\
\hline H & 217.0 & \pm & 11.9 & 4.73 & \pm & 0.20 \\
\hline D & 189.1 & \pm & 10.6 & 3.31 & \pm & 0.24 \\
\hline HD & 191.5 & \pm & 6.8 & 3.08 & \pm & 0.17 \\
\hline
\end{tabular}


Table 3. Abundances (in \%) of the quantitatively prominent OTUs contributing the most to the dissimilarity among the inoculum sample (I) and the end points of the microcosms with additions of humic matter (H), Daphnia carcasses (D), humic matter and carcasses together (HD), and blank with no carbon sources (B). Values are given as means of five replicates \pm standard errors, except for the inoculum sample obtained from a single measurement, and $\mathbf{B}$ microcosms (four replicates due to low DNA content of two samples which were pooled).

\begin{tabular}{|c|c|c|c|c|c|c|c|c|c|c|c|c|c|c|c|c|c|}
\hline OTU & $\mathbf{I}$ & B & & & $\mathbf{H}$ & & & D & & & HD & & & Genus & Family & Class & Phyla \\
\hline 1 & 6.84 & 17.80 & \pm & 3.96 & 3.95 & \pm & 0.40 & 45.63 & \pm & 2.39 & 57.39 & \pm & 1.41 & Pseudomonas & Pseudomonadaceae & Gammaproteobacteria & Proteobacteria \\
\hline 2 & 1.31 & 2.90 & \pm & 1.14 & 3.53 & \pm & 0.35 & 15.82 & \pm & 1.16 & 5.40 & \pm & 0.38 & Duganella & Oxalobacteraceae & Betaproteobacteria & Proteobacteria \\
\hline 3 & 1.33 & 0.76 & \pm & 0.06 & 0.24 & \pm & 0.07 & 9.11 & \pm & 1.07 & 7.42 & \pm & 0.32 & Flavobacterium & Flavobacteriaceae & Flavobacteriia & Bacteroidetes \\
\hline 4 & 20.91 & 7.66 & \pm & 0.25 & 9.32 & \pm & 0.94 & 0.19 & \pm & 0.02 & 0.57 & \pm & 0.04 & Polynucleobacter & Burkholderiaceae & Betaproteobacteria & Proteobacteria \\
\hline 5 & 0.08 & 0.06 & \pm & 0.03 & 0.09 & \pm & 0.03 & 5.83 & \pm & 0.70 & 4.13 & \pm & 0.44 & Janthinobacterium & Oxalobacteraceae & Betaproteobacteria & Proteobacteria \\
\hline 6 & 0.29 & 0.07 & \pm & 0.01 & 19.64 & \pm & 4.40 & 0.27 & \pm & 0.10 & 0.63 & \pm & 0.14 & vadinHA64 & Opitutae & Opitutae & Verrucomicrobia \\
\hline 7 & 0.01 & 12.35 & \pm & 4.10 & 4.61 & \pm & 1.25 & 0.21 & \pm & 0.06 & 0.02 & \pm & 0.01 & Rhizobacter & Comamonadaceae & Betaproteobacteria & Proteobacteria \\
\hline 8 & 0.32 & 7.14 & \pm & 0.87 & 7.88 & \pm & 0.80 & 0.03 & \pm & 0.01 & 0.33 & \pm & 0.06 & uncultured & uncultured & Thermoleophilia & Actinobacteria \\
\hline 9 & 3.49 & 8.08 & \pm & 1.28 & 4.06 & \pm & 0.70 & 0.47 & \pm & 0.03 & 0.30 & \pm & 0.03 & Reyranella & Rhodospirillales InsSed & Alphaproteobacteria & Proteobacteria \\
\hline 10 & 15.52 & 6.24 & \pm & 0.31 & 0.92 & \pm & 0.30 & 0.03 & \pm & 0.01 & 0.03 & \pm & 0.01 & FukuN18 & FukuN18 & Spartobacteria & Verrucomicrobia \\
\hline 11 & 0.22 & 0.04 & \pm & 0.01 & 0.17 & \pm & 0.09 & 1.40 & \pm & 0.15 & 2.81 & \pm & 0.20 & uncultured & Chitinophagaceae & Sphingobacteriia & Bacteroidetes \\
\hline 12 & 4.94 & 5.36 & \pm & 0.39 & 2.21 & \pm & 0.17 & 0.14 & \pm & 0.01 & 0.20 & \pm & 0.02 & Mycobacterium & Mycobacteriaceae & Actinobacteria & Actinobacteria \\
\hline 13 & 0.14 & 0.07 & \pm & 0.02 & 0.07 & \pm & 0.02 & 1.98 & \pm & 0.40 & 2.01 & \pm & 0.67 & Pseudomonas & Pseudomonadaceae & Gammaproteobacteria & Proteobacteria \\
\hline 16 & 0.00 & 0.03 & \pm & 0.02 & 2.63 & \pm & 0.70 & 0.82 & \pm & 0.12 & 0.70 & \pm & 0.10 & Alkanibacter & Nevskiaceae & Gammaproteobacteria & Proteobacteria \\
\hline 19 & 0.07 & 0.08 & \pm & 0.01 & 0.02 & \pm & 0.01 & 0.00 & \pm & 0.00 & 1.86 & \pm & 0.37 & Bacteriovorax & Bacteriovoracaceae & Deltaproteobacteria & Proteobacteria \\
\hline 20 & 0.01 & 0.00 & \pm & 0.00 & 0.05 & \pm & 0.02 & 0.91 & \pm & 0.28 & 0.79 & \pm & 0.28 & OPS17 & env.OPS_17 & Sphingobacteriia & Bacteroidetes \\
\hline 25 & 4.74 & 0.98 & \pm & 0.11 & 0.69 & \pm & 0.04 & 0.01 & \pm & 0.00 & 0.03 & \pm & 0.01 & unclassified & Sporichthyaceae & Actinobacteria & Actinobacteria \\
\hline 28 & 3.60 & 1.43 & \pm & 0.22 & 0.29 & \pm & 0.08 & 0.01 & \pm & 0.00 & 0.01 & \pm & 0.00 & uncultured & Planctomycetaceae & Planctomycetacia & Planctomycetes \\
\hline 29 & 2.85 & 1.09 & \pm & 0.07 & 0.86 & \pm & 0.07 & 0.01 & \pm & 0.00 & 0.03 & \pm & 0.00 & PRD01a011B & Methylophilaceae & Betaproteobacteria & Proteobacteria \\
\hline 30 & 0.14 & 0.02 & \pm & 0.00 & 2.53 & \pm & 0.81 & 0.00 & \pm & 0.00 & 0.09 & \pm & 0.02 & Prosthecobacter & Verrucomicrobiaceae & Verrucomicrobiae & Verrucomicrobia \\
\hline 33 & 0.00 & 0.00 & \pm & 0.00 & 0.01 & \pm & 0.01 & 0.71 & \pm & 0.32 & 0.54 & \pm & 0.33 & OPS17 & env.OPS_17 & Sphingobacteriia & Bacteroidetes \\
\hline 34 & 0.00 & 0.55 & \pm & 0.24 & 2.01 & \pm & 0.82 & 0.00 & \pm & 0.00 & 0.00 & \pm & 0.00 & Zoogloea & Rhodocyclaceae & Betaproteobacteria & Proteobacteria \\
\hline 39 & 1.96 & 0.16 & \pm & 0.01 & 0.04 & \pm & 0.01 & 0.03 & \pm & 0.02 & 0.42 & \pm & 0.06 & Flavobacterium & Flavobacteriaceae & Flavobacteriia & Bacteroidetes \\
\hline 55 & 1.97 & 0.34 & \pm & 0.05 & 0.16 & \pm & 0.02 & 0.00 & \pm & 0.00 & 0.01 & \pm & 0.00 & unclassified & Sporichthyaceae & Actinobacteria & Actinobacteria \\
\hline 64 & 1.42 & 0.12 & \pm & 0.01 & 0.13 & \pm & 0.01 & 0.01 & \pm & 0.00 & 0.03 & \pm & 0.01 & hgcl & Sporichthyaceae & Actinobacteria & Actinobacteria \\
\hline
\end{tabular}




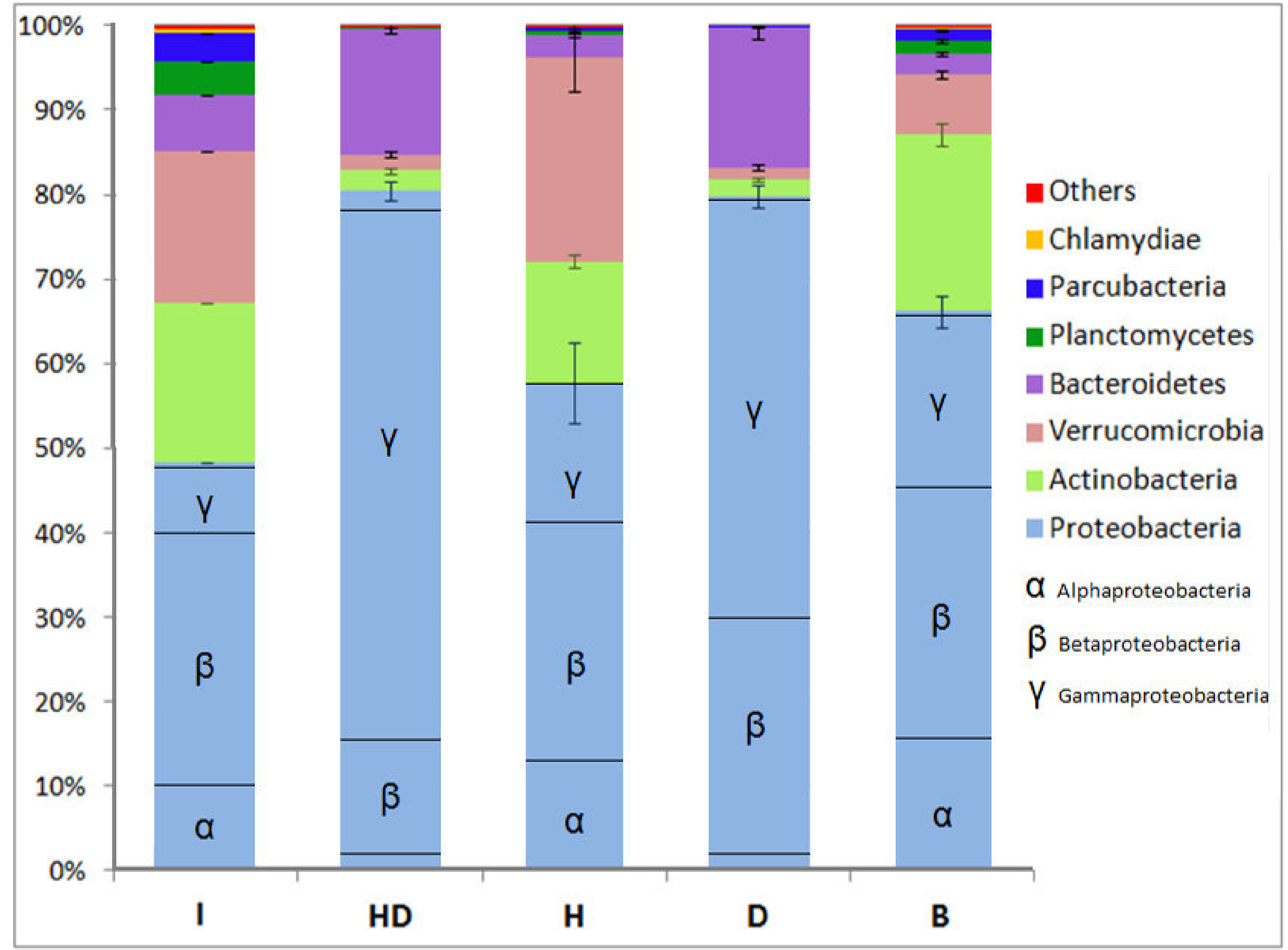



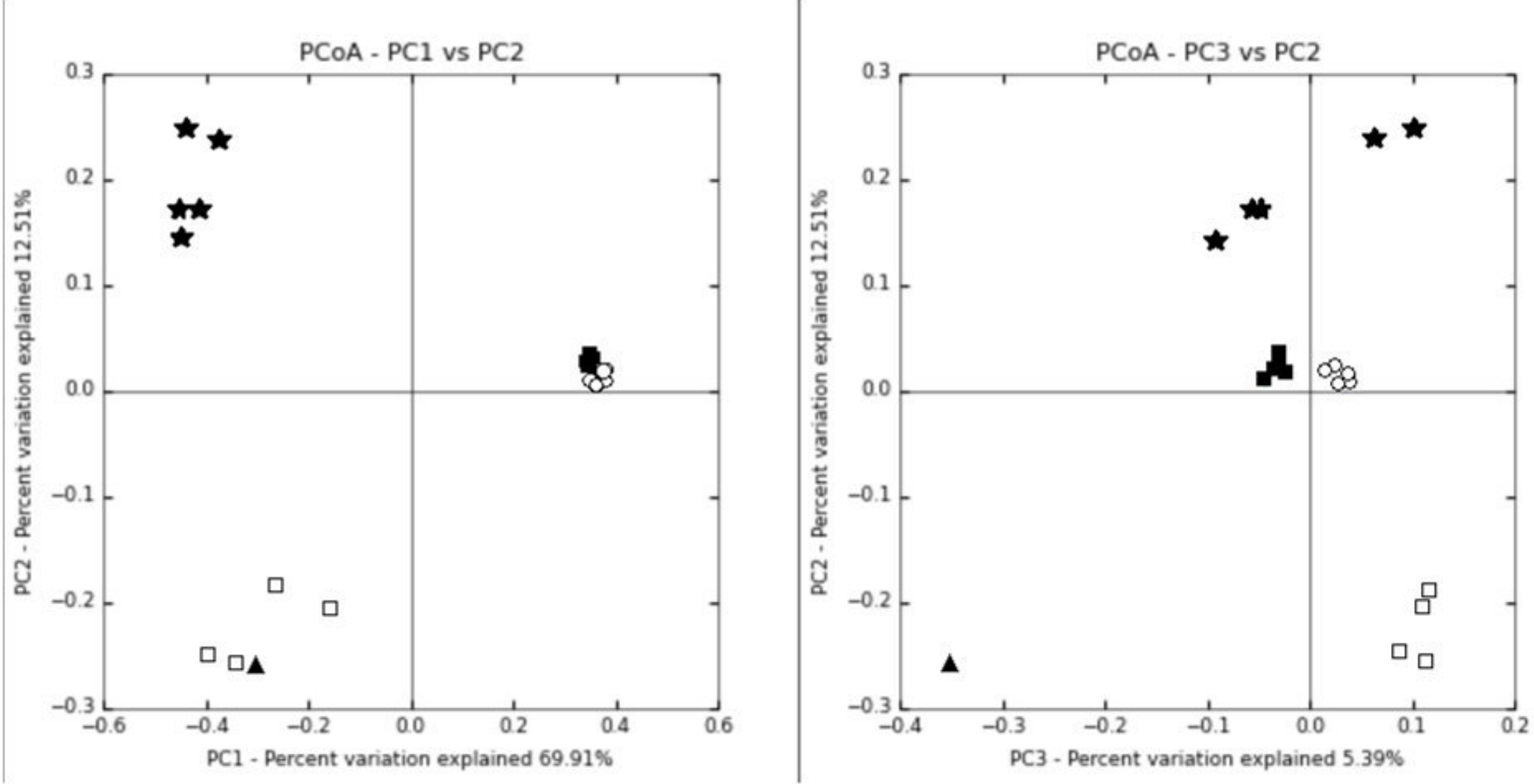

A I

ㅁ $\mathbf{B}$

$\star \mathrm{H}$

- D

- HD 


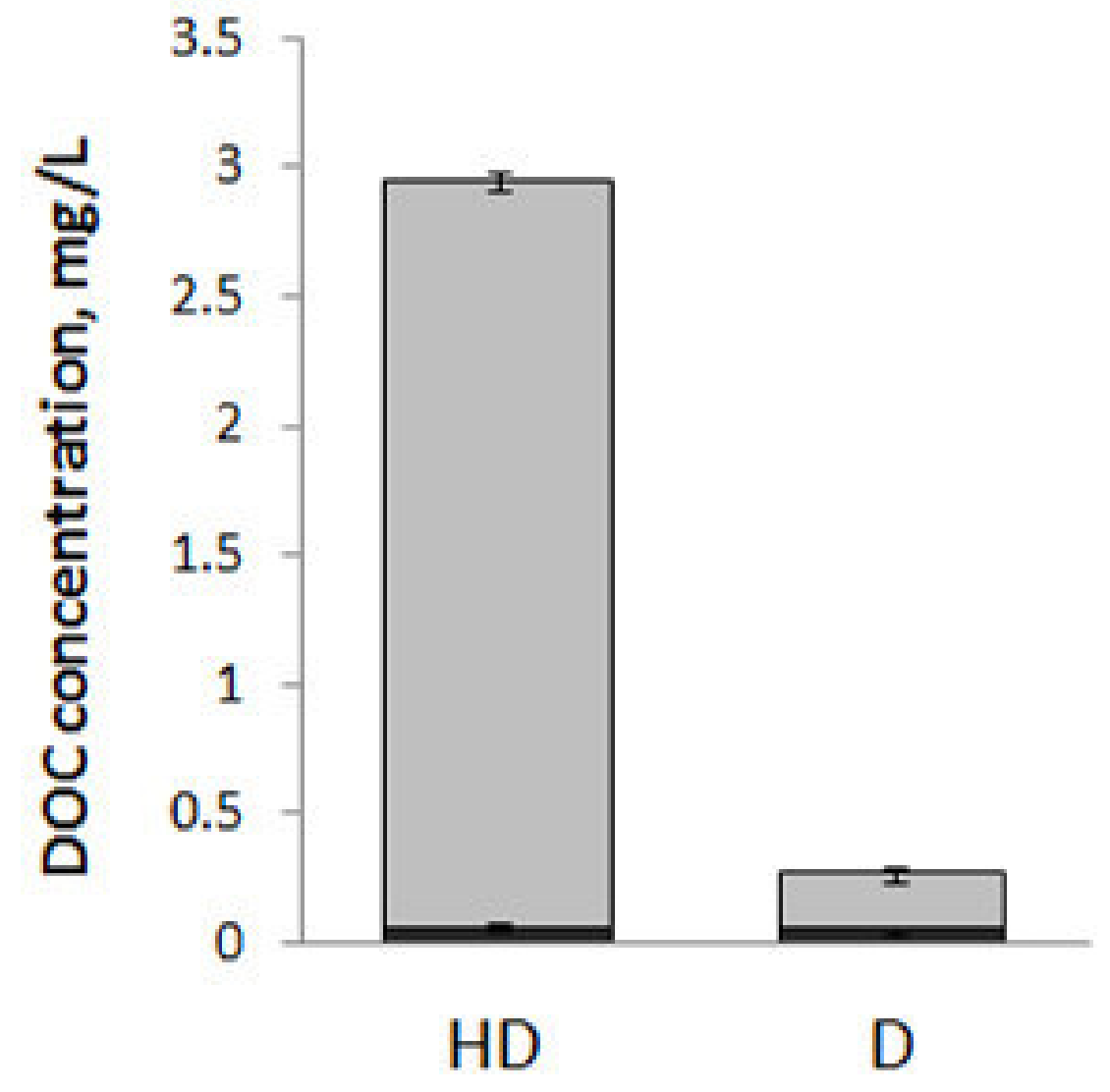

- carbon dervied from carcasses

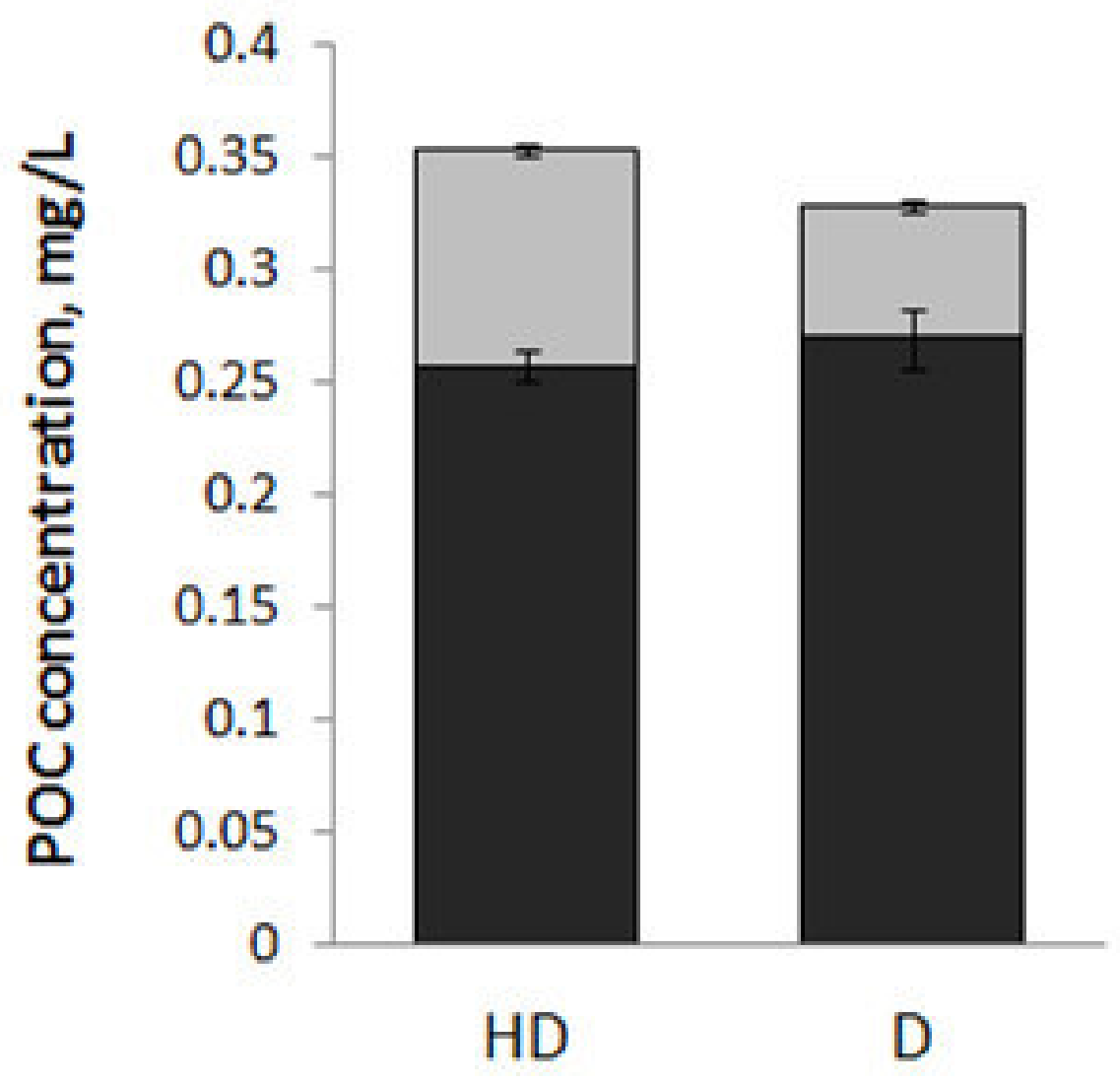

$\square$ carbon derived from other sources 
a

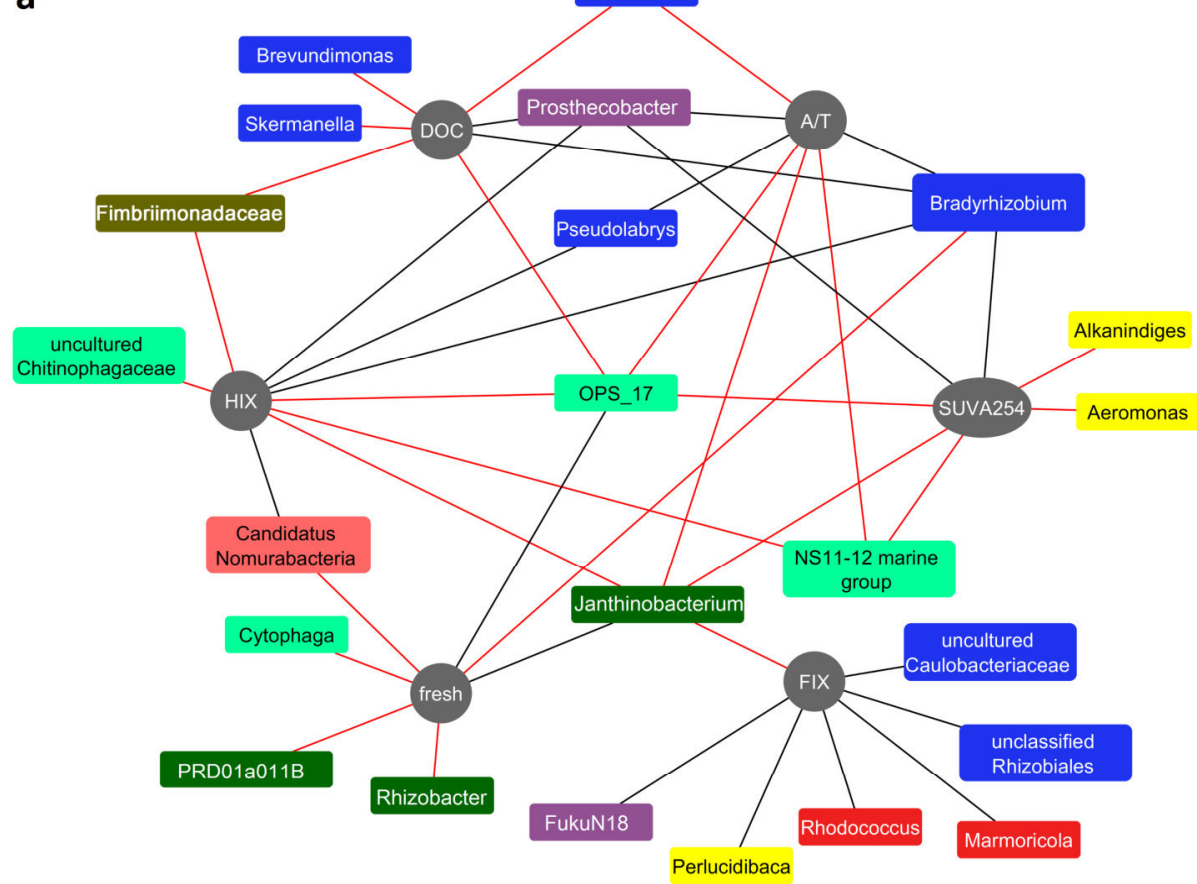

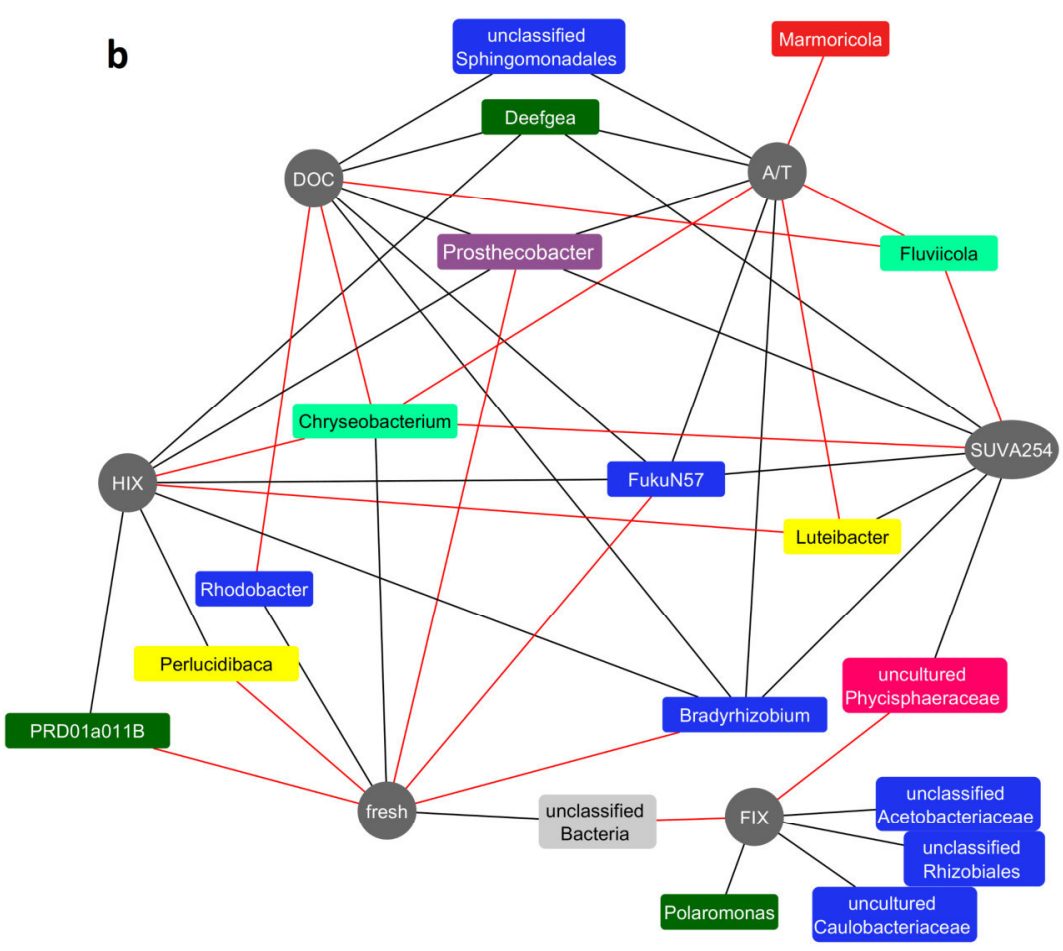

Color code

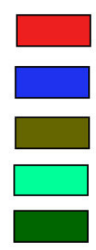

Actinobacteria

Alphaproteobacteria

Armatimonadetes

Bacteroidetes

Betaproteobacteria $\square$ Candidatus Nomurabacteria

Chloroflexi

Gammaproteobacteria

Planctomycetes

Verrucomicrobia 


\section{Supplementary Information}

\section{Community composition in different microcosms}

Actinobacteria and Verrucomicrobia had comparatively high abundances in the initial inoculum (19\% and 18\%, respectively), but their final abundance diverged in different treatments (Fig. 1). While in HD and D microcosms both phyla decreased down to $1-2 \%$ of total abundance, in $\mathbf{H}$ microcosms Verrucomicrobia increased to $24 \%$, and Actinobacteria slightly decreased to $14 \%$ at the end of the incubation. In contrast, Actinobacteria increased in abundance (to $21 \%$ ) and Verrucomicrobia decreased (to $7 \%$ ) at the end of the incubation in the $\mathbf{B}$ microcosms (Fig. 1).

Initially, the relative abundance of Bacteroidetes was 7\%, increasing to $15 \%$ and 17 $\%$ in the HD and D microcosms, respectively (Fig. 1). At the end of the incubation, only $3 \%$ of sequences in $\mathbf{H}$ microcosms and $2 \%$ of sequences in $\mathbf{B}$ microcosms belonged to Bacteroidetes. Members of the candidate phylum Parcubacteria initially accounted for 3\% of all sequences, but dropped in all treatments. All other identified phyla did not exceed a threshold of $1 \%$ in any sample.

In the bacterial inoculum from Lake Grosse Fuchskuhle, OTU4 Polynucleobacter sp. from the class Betaproteobacteria dominated (21\%, Table 3). OTU10 FukuN18 (Verrucomicrobia) was the second numerous OTU (16\%, Table 3$)$ in the natural community. However, at the end of the experiment, both OTUs decreased in all microcosms, especially in the $\mathbf{H D}$ and $\mathbf{D}$ microcosms $(<1 \%$, Table 3$)$.

In the B microcosms, OTU1 Pseudomonas from the class Gammaproteobacteria, which was also present in the initial sample with $7 \%$, became dominant (18\%), and OTU7 Rhizobacter (Betaproteobacteria) considerably increased from almost absent to $12 \%$ (Table $3)$.

In the $\mathbf{H}$ microcosms, OTU4 Polynucleobacter decreased to $9 \%$ of all sequences representing the second most abundant member of the community (Table 3). Instead, OTU6 
vadinHA64 (Opitutae, Verrucomicrobia) became dominant (20\%) in the $\mathbf{H}$ microcosm, but did not increase in any other microcosm. Microcosms $\mathbf{H}$ were characterized by higher fractions of OTU15 Aquabacterium, OTU16 Alkanibacter, OTU30 Prosthecobacter and OTU34 Zoogloea when compared to other microcosms.

In both D and HD microcosms, OTU1 Pseudomonas was dominant (46 \% and $57 \%$, respectively; Table 3). In the D microcosm, OTU2 Duganella (Betaproteobacteria) was remarkably more abundant than in other treatments (16\%). OTU3 Flavobacterium (Bacteroidetes) was also highly abundant in D and HD microcosms (9\% and $7 \%$, respectively). Other OTUs were enriched in the HD and D microcosms: OTU 5 Janthinobacterium, OTU11 uncultured Chitinophagaceae, OTU13 Pseudomonas (Table 3). Interestingly, OTU19 Bacteriovorax was enriched only in the HD microcosms (Table 3).

Overall, the diversity of bacterial communities decreased with the total amount of available LOM (Table 2), indicating the copiotrophic nature of the dominant Gammaproteobacteria. Microcosms B (no OM addition) supported the bacterial community which remained most similar to the initial inoculum I (Fig. 2). The dissimilarity between the initial inoculum and microcosms $\mathbf{B}$ was mainly caused by the dominance of OTU4 Polynucleobacter (Table S1) in the initial sample. This group of bacteria represents a common genus of freshwater bacterioplankton communities (Hahn et al., 2009), and has been described earlier for Lake Grosse Fuchskuhle (Hutalle-Schmelzer et al., 2010). Several Polynucleobacter clades prefer acidic lakes and have been shown to assimilate the breakdown products of humic matter (Newton et al., 2011), but not humic matter itself (HutalleSchmelzer et al., 2010). At the end of the experiment, Pseudomonas represented the most dominant genus in microcosms $\mathbf{D}$ and HD, but was also abundant in microcosms B (Table 3). This particular genus contributed the most to the observed differences between HD, D and all other microcosms (OTU1, Table S1), but it represents a taxonomically and physiologically diverse group, including putrefactive (Pekhtasheva, 2012) and chitinolytic bacteria (Gooday, 
53

1990). Our data suggest that Pseudomonas are greatly favored by the presence of the relatively labile organic carbon pool derived from zooplankton carcasses indicating the high potential of carcasses to select for specific bacterial communities different from those in Lake Grosse Fuchskuhle and other lakes.

Bacterial communities of microcosms HD and D were very similar (Fig. 2) and characterized by a high abundance of copiotrophs adapted to high nutrient availability, and chitinolytic bacteria, i.e. Flavobacterium (Gooday, 1990; Newton et al., 2011), Janthinobacterium, Duganella (Haack et al., 2016) and uncultured representatives of Chitinophagaceae (Kämpfer, 2015).

In the $\mathbf{H}$ microcosms, the dominant OTU6 vadinHA64 (Opitutae, Verrucomicrobia, Table 3) is of a particular interest due to its ability to benefit from humic matter additions. However, only limited information is available about this so far uncultivated and uncharacterized strain.

\section{References}

Gooday, G.W. (1990). The ecology of chitin degradation. In: Marshall KC (ed). Advances in Microbial Ecology. Springer US: Boston, MA, pp 387-430.

Haack, F.S., Poehlein, A., Kröger, C., Voigt, C.A., Piepenbring, M., Bode, H.B., et al. (2016). Molecular keys to the Janthinobacterium and Duganella spp. interaction with the plant pathogen Fusarium graminearum. Front Microbiol 7. e-pub ahead of print, doi: 10.3389/fmicb.2016.01668.

Hahn, M.W., Lang, E., Brandt, U., Wu, Q.L., Scheuerl, T. (2009). Emended description of the genus Polynucleobacter and the species $P$. necessarius and proposal of two subspecies, P. necessarius subspecies necessarius subsp. nov. and P. necessarius subsp. a symbioticus subsp. nov. Int J Syst Evol Microbiol 59: 2002-2009. 
77 Hutalle-Schmelzer, K.M.L., Zwirnmann, E., Krüger, A., Grossart, H-P. (2010). Enrichment and cultivation of pelagic bacteria from a humic lake using phenol and humic matter additions. FEMS Microbiol Ecol 72: 58-73.

Kämpfer, P. (2015). Sphingobacteriales ord. nov. In: Bergey's Manual of Systematics of Archaea and Bacteria. John Wiley \& Sons, Ltd. e-pub ahead of print, doi: 10.1002/9781118960608.obm00034.

Newton, R.J., Jones, S.E., Eiler, A., McMahon, K.D., Bertilsson, S. (2011). A guide to the natural history of freshwater lake bacteria. Microbiol Mol Biol Rev 75: 14-49.

Pekhtasheva, E.L. (2012). Biodamage and biodegradation of polymeric materials. Smithers Rapra, 258 p. 
2

3

4

5

6

7

\section{Microcosm medium and added substrates}

\section{Artificial lake water}

Artificial lake water was prepared following the protocol for acidic waters of Smith et al. (2002), but excluding the addition of aluminum chloride. The $\mathrm{pH}$ was corrected to 5.3 to match the original $\mathrm{pH}$ of Lake Grosse Fuchskuhle at the time of sampling. $1.6 \mathrm{mg} \mathrm{L}^{-1}$ of nitrate and $0.36 \mathrm{mg} \mathrm{L}^{-1}$ of phosphate were added to avoid nutrient limitation. Each microcosm was filled with $499 \mathrm{~mL}$ of artificial lake water.

\section{Bacterial community and humic matter}

The bacterial source community was obtained from the north-eastern basin of the artificially divided lake Grosse Fuchskuhle (Grossart et al., 2008; Hutalle-Schmelzer et al., 2010), which is fed by waters of a surrounding bog, thus most of its dissolved organic matter is composed of humic matter. After preliminary filtration of lake water through $0.8 \mu \mathrm{m}$ for elimination of grazers as previously described in other degradation studies (HutalleSchmelzer et al., 2010; Attermeyer et al., 2014), the bacterial community was concentrated by tangential flow filtration and further centrifugation $\left(30 \mathrm{~min}\right.$ at $8000 \mathrm{rpm}$ at $\left.4^{\circ} \mathrm{C}\right)$. The bacterial pellet was then transferred to PBS buffer and kept overnight at $4{ }^{\circ} \mathrm{C}$ prior inoculation of $1 \mathrm{~mL}$ into each microcosm as in Attermeyer et al. (2014).

Humic matter previously extracted from the south-western part of Lake Grosse Fuchskuhle by reverse osmosis was used as a ROM source (Hutalle-Schmelzer et al., 2010). The humic extract was diluted, filtered through $0.45 \mu \mathrm{m}$, and added to microcosms $\mathbf{H D}$ and $\mathbf{H}$ (mean final concentration $3.025 \pm 0.070 \mathrm{mg} \mathrm{C} \mathrm{L}^{-1}$ ). The $\mathrm{ROM}$ added to the microcosms had a signature of $\delta^{13} \mathrm{C}=-6.28 \%$. 
${ }^{13}$ C-labeled zooplankton carcasses

A culture of Daphnia magna was fed with Scenedesmus quadricauda grown in modified Z-medium (Schlösser, 1994), containing ${ }^{13} \mathrm{C}$-labeled sodium bicarbonate (Sigma Aldrich, 98 atom $\%{ }^{13} \mathrm{C}$ ). Just before starting the experiment, daphnids were killed by short exposure to $10 \%$ acetic acid and thereafter rinsed several times in ultrapure water (Tang et al., 2006). Carcasses were manually divided into equal groups by numbers and size, and adjusted to even out the weights of individual groups before inoculation to reach a homogenous distribution of both carcasses mass and length between all HD and D microcosms. We selected the number of carcasses (20 per microcosm) to be as close as possible to natural values (Dubovskaya et al., 2003). The carbon content of a subset of acid-killed daphnids was detected by a carbon analyzer Eltra SC 800 (Eltra, Germany) to estimate the surplus of carbon introduced by carcasses supply.

\section{DNA extraction}

Zirconium and glass beads of various diameter and $0.6 \mathrm{~mL}$ CTAB (cetyltrimethylammonium bromide) buffer were added to the samples. Then $60 \mu \mathrm{l}$ of $10 \%$ sodium dodecyl sulfate (w:v), $60 \mu 1$ of $10 \% \mathrm{~N}$-Lauroylsarcosin (w:v), and $0.6 \mathrm{~mL}$ of $\mathrm{pH}-$ neutral phenolchloroform-isoamylalcohol mixture (25:24:1, v:v:v) were added. Samples were homogenized on a vortexer for $10 \mathrm{~min}$ at highest speed and then centrifuged at $16000 \times \mathrm{g}$ for $10 \mathrm{~min}$ at $4{ }^{\circ} \mathrm{C}$. The aqueous phase was transferred into new reaction tubes, washed with 1 volume of chloroform-isoamylalcohol (24:1, v:v) and centrifuged at $16000 \times \mathrm{g}$ for $10 \mathrm{~min}$ at $4{ }^{\circ} \mathrm{C}$. Again, the aqueous phase was transferred into new reaction tubes and mixed with 2 volumes of $30 \%$ polyethylene glycol (w:v) in $1.6 \mathrm{M} \mathrm{NaCl}$. After incubation for $1.5 \mathrm{~h}$ at $4{ }^{\circ} \mathrm{C}$ samples were centrifuged at $17000 \times \mathrm{g}$ for $60 \mathrm{~min}$ at $4{ }^{\circ} \mathrm{C}$. The supernatant was removed and the pellet was washed with $1 \mathrm{~mL}$ of ice-cold $70 \%$ ethanol. After centrifugation at $17000 \times \mathrm{g}$ for $10 \mathrm{~min}$ the 
supernatant was removed and the nucleic acid pellet was air-dried and finally dissolved in 50 $\mu \mathrm{L}$ ultra-pure water.

\section{Sequencing data processing}

Sequences with an average quality of $<25$ over a $50 \mathrm{bp}$ window, that were shorter than 300 bp or which contained ambiguities and homopolymer stretches of more than 8 bases were excluded from further analysis. Chimera check was performed using UCHIME (Edgar et al., 2011). Taxonomy assignment of the OTUs was done using a naïve Bayesian classifier (Wang et al., 2007) and the SILVA reference database v128 with a confidence threshold of $80 \%$. All sequences classified as unknown, eukaryote, mitochondrion, chloroplast and archaea were subsequently removed. Sequences were then clustered into operational taxonomic units (OTU) using VSEARCH (Rognes et al., 2016); as implemented in Mothur with a minimum sequence similarity value of $97 \%$ and global singleton sequences were removed.

\section{Carbon decomposition calculations}

The initial amount of carbon in $\mathbf{D}$ microcosms is presumed to be equal to the initial blank plus carbon of the added Daphnia carcasses $1.334 \pm 0.038 \mathrm{mg} \mathrm{L}^{-1}$. Accordingly, the initial amount of carbon in the HD microcosms, $\mathrm{TOC}_{\mathrm{i}}(\mathrm{HD})$, equals to the sum of total organic carbon in $\mathbf{H}$ microcosms, $\mathrm{TOC}_{\mathrm{i}}(\mathrm{H})$, and carbon of the added carcasses. Total carbon degradation throughout the experiment was calculated in each microcosm as a difference between the final and initial TOC concentration:

$$
\Delta \mathrm{TOC}=\mathrm{TOC}_{\mathrm{f}}-\mathrm{TOC}_{\mathrm{i}}
$$

Predicted total degradation of carbon in HD microcosms was computed as:

$$
\Delta \mathrm{TOC}(\mathrm{H}+\mathrm{D})=\Delta \mathrm{TOC}(\mathrm{H})+\Delta \mathrm{TOC}(\mathrm{D})-\Delta \mathrm{TOC}(\mathrm{B})
$$

The carcass carbon fraction $\left(\mathrm{F}_{\mathrm{c}}\right)$ in DOC and POC was calculated from the stable isotope mixing model (Hopkins and Ferguson, 2012):

$$
\mathrm{F}_{\mathrm{c}}=\left(\mathrm{d}_{\mathrm{x}}-\mathrm{d}_{\mathrm{h}}\right) /\left(\mathrm{d}_{\mathrm{c}}-\mathrm{d}_{\mathrm{h}}\right)
$$


where $\mathrm{d}_{\mathrm{x}}$ is $\delta^{13} \mathrm{C}(\%)$ of the DOC or POC at the end of the experiment, $\mathrm{d}_{\mathrm{c}}$ is $\delta^{13} \mathrm{C}(\% \mathrm{o})$ of Daphnia carcasses and $\mathrm{d}_{\mathrm{h}}$ is $\delta^{13} \mathrm{C}(\% \mathrm{o})$ of humic matter.

\section{Carbon respiration calculations}

In parallel, we computed ${ }^{13} \mathrm{CO}_{2}$ respiration rate as a result of carcass carbon degradation in $\mathbf{D}$ microcosms, representing the difference between final concentrations of ${ }^{13} \mathrm{CO}_{2}$ in $\mathbf{D}$ and $\mathbf{B}$ microcosms:

$$
{ }^{13} \Delta \mathrm{CO}_{2} \text { (carcasses) }={ }^{13} \mathrm{CO}_{2}(\mathrm{D})-{ }^{13} \mathrm{CO}_{2}(\mathrm{~B})
$$

Similarly, the quantity of ${ }^{13} \mathrm{CO}_{2}$ respired from humic matter degradation in $\mathbf{H}$ microcosms was obtained from:

$$
\Delta{ }^{13} \mathrm{CO}_{2}(\text { humics })={ }^{13} \mathrm{CO}_{2}(\mathrm{H})-{ }^{13} \mathrm{CO}_{2}(\mathrm{~B})
$$

Then, we predicted ${ }^{13} \mathrm{CO}_{2}$ concentration at the final point of the experiment if carcasses and humic matter were degraded together in one microcosm without any priming effect:

$$
\begin{aligned}
& { }^{13} \mathrm{CO}_{2}(\mathrm{H}+\mathrm{D})=\Delta{ }^{13} \mathrm{CO}_{2} \text { (carcasses) }+\Delta{ }^{13} \mathrm{CO}_{2} \text { (humics) }+{ }^{13} \mathrm{CO}_{2}(\mathrm{~B})={ }^{13} \mathrm{CO}_{2}(\mathrm{D})+ \\
& +{ }^{13} \mathrm{CO}_{2}(\mathrm{H})-{ }^{13} \mathrm{CO}_{2}(\mathrm{~B})
\end{aligned}
$$

The same calculations (Eq. 3-5) were done for ${ }^{12} \mathrm{CO}_{2}$, and the predicted ratio ${ }^{13} \mathrm{CO}_{2}(\mathrm{H}+\mathrm{D}) /{ }^{12} \mathrm{CO}_{2}(\mathrm{H}+\mathrm{D})$ was computed. The result was compared with the observed ratio ${ }^{13} \mathrm{CO}_{2}(\mathrm{HD}) /{ }^{12} \mathrm{CO}_{2}(\mathrm{HD})$.

For calculating the carcass carbon fraction $\left(\mathrm{F}_{\mathrm{c}^{\prime}}\right)$ in the respired $\mathrm{CO}_{2}$ of the $\mathrm{HD}$ microcosms we used the stable isotope mixing model:

$$
\mathrm{F}_{\mathrm{c}}=\left(\mathrm{d}_{\mathrm{x}^{\prime}}-\mathrm{d}_{\mathrm{h}}\right) /\left(\mathrm{d}_{\mathrm{c}}-\mathrm{d}_{\mathrm{h}}\right)
$$

where $\mathrm{d}_{\mathrm{x}}$, is the $\delta^{13} \mathrm{C}(\%)$ of the dissolved $\mathrm{CO}_{2}$ at the end of the experiment, $\mathrm{d}_{\mathrm{c}}$ is $\delta^{13} \mathrm{C}$ (\%) of respired $\mathrm{CO}_{2}$ originating from Daphnia carcasses, and $\mathrm{d}_{\mathrm{h}}$ is $\delta^{13} \mathrm{C}(\%)$ of respired $\mathrm{CO}_{2}$ originating from humic matter. 


\section{References}

Attermeyer, K., Hornick, T., Kayler, Z.E., Bahr, A., Zwirnmann, E., Grossart, H.-P., and Premke, K. (2014) Enhanced bacterial decomposition with increasing addition of autochthonous to allochthonous carbon without any effect on bacterial community composition. Biogeosciences 11: 1479-1489.

Dubovskaya, O.P., Gladyshev, M.I., Gubanov, V.G., and Makhutova, O.N. (2003) Study of non-consumptive mortality of Crustacean zooplankton in a Siberian reservoir using staining for live/dead sorting and sediment traps. Hydrobiologia 504: 223-227.

Edgar, R.C., Haas, B.J., Clemente, J.C., Quince, C., and Knight, R. (2011) UCHIME improves sensitivity and speed of chimera detection. Bioinformatics. 27: 2194-2200.

Grossart, H.-P., Jezbera, J., Hornak, K., Hutalle, K.M.L., Buck, U., and Simek, K. (2008) Top-down and bottom-up induced shifts in bacterial abundance, production and community composition in an experimentally divided humic lake. Environ Microbiol 10: $635-652$.

Hopkins, J.B. and Ferguson, J.M. (2012) Estimating the diets of animals using stable isotopes and a comprehensive Bayesian mixing model. PLoS ONE 7: e28478.

Hutalle-Schmelzer, K.M.L., Zwirnmann, E., Krüger, A., and Grossart, H.-P. (2010) Enrichment and cultivation of pelagic bacteria from a humic lake using phenol and humic matter additions. FEMS Microbiol Ecol 72: 58-73.

Rognes, T., Flouri, T., Nichols, B., Quince, C., and Mahé, F. (2016) VSEARCH: a versatile open source tool for metagenomics. PeerJ 4: e2584.

Schlösser, U.G. (1994) SAG - Sammlung von Algenkulturen at the University of Göttingen Catalogue of Strains 1994. Bot Acta 107: 113-186.

Smith, E.J., Davison, W., and Hamilton-Taylor, J. (2002) Methods for preparing synthetic freshwaters. Water Res 36: 1286-1296. 
123 Tang, K.W., Hutalle, K.M.L., and Grossart, H. (2006) Microbial abundance, composition and enzymatic activity during decomposition of copepod carcasses. Aquat Microb Ecol.45: 219-227.

126 Wang, Q., Garrity, G.M., Tiedje, J.M., and Cole, J.R. (2007) Naïve Bayesian classifier for rapid assignment of rRNA sequences into the new bacterial taxonomy. Appl. Environ. Microbiol. 73: 5261-5267. 


\section{Supplementary Figure Legends}

Fig. S1 Experimental setup with blank controls (right, B), single-source incubations (middle, $\mathbf{D}$ and $\mathbf{H}$ ), and mixed treatments (left, HD). Microcosms were 1L glass bottles halffilled with artificial lake water and inoculated with a natural bacterial community. Each type of microcosm is represented by five replicates.

Fig. S2 Microscopic observations of Daphnia magna carcasses decomposition during the first 5 days of the experiment: $\mathbf{a}$ - Day 0; b - Day 1; c-Day 2; d - Day 3-5. After day 3, differences in individual carcasses conditions are noticeable. After day 5, all carcasses fell apart into pieces; $\mathbf{e}$-DAPI-stained carcass colonized by bacterial cells at day 15 .

Fig. S3 Change in concentrations of ${ }^{12} \mathrm{CO}_{2}$ and ${ }^{13} \mathrm{CO}_{2}$ compared to the blank microcosm in the final points of experimental microcosms with different organic carbon sources: humic matter (H), Daphnia carcasses (D), humic matter and carcasses together (HD). 


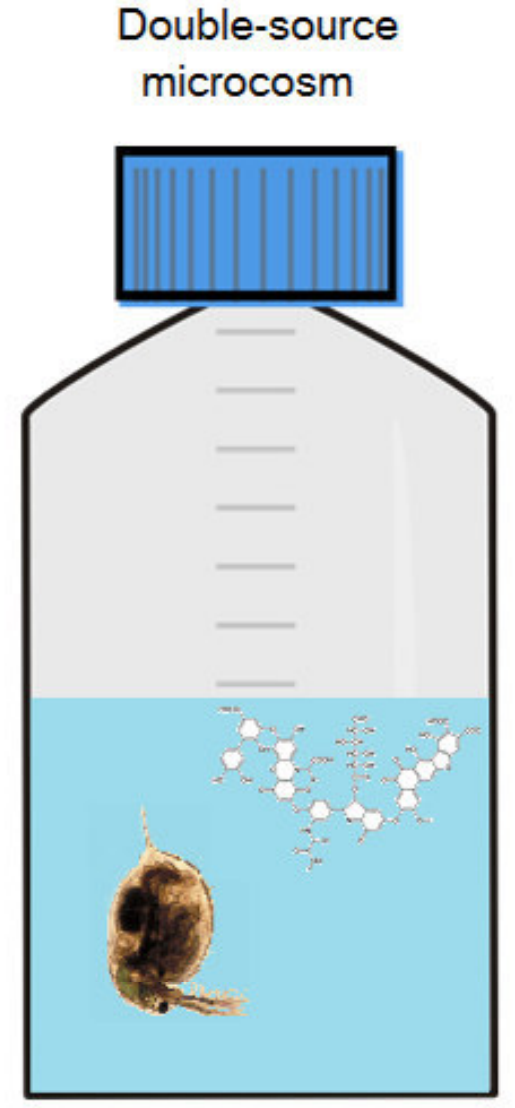

Humic matter + daphnia carcasses
Single-source microcosms

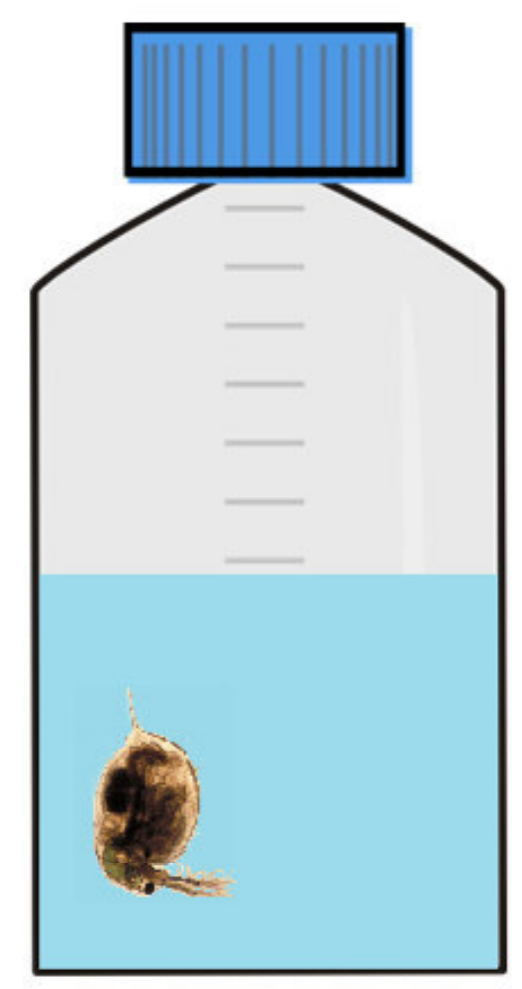

Daphnia carcasses

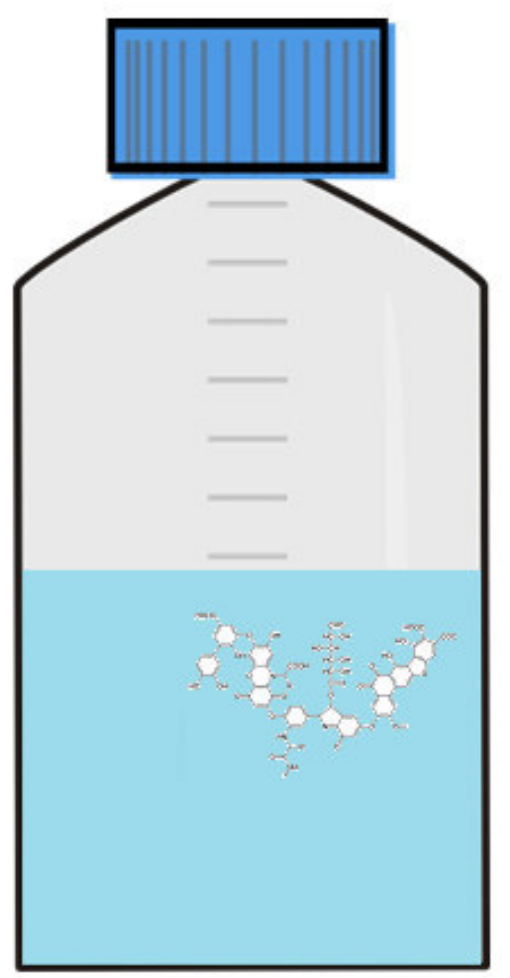

Humic matter
Blank

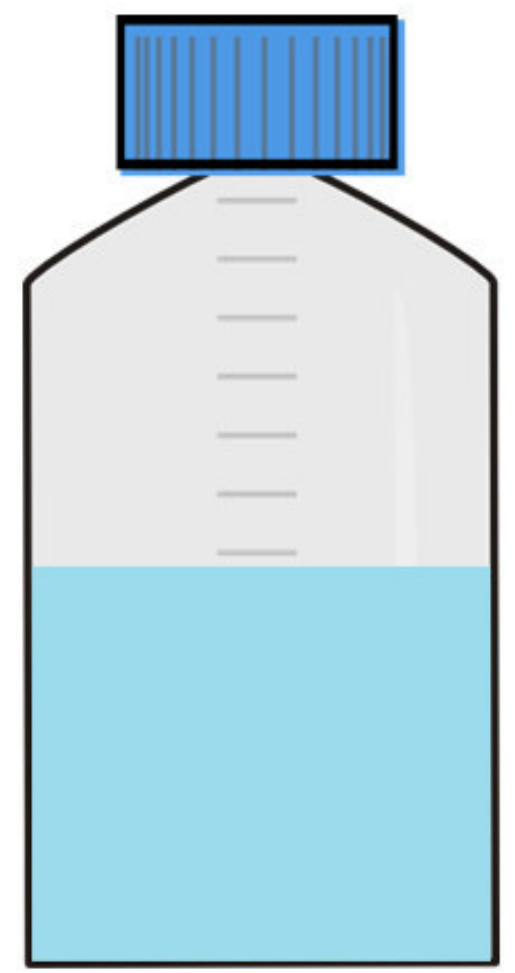

$\mathrm{H}$ 

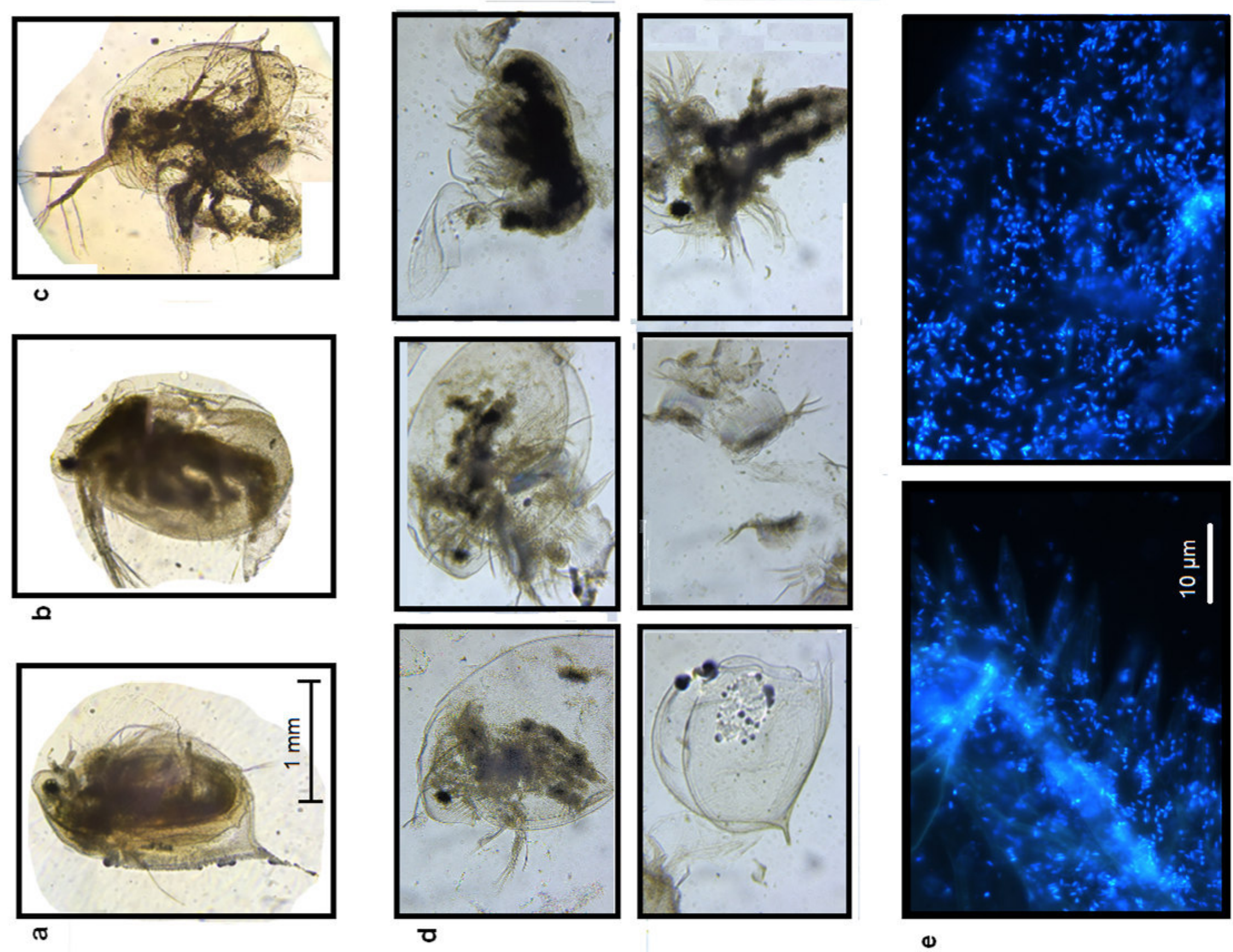


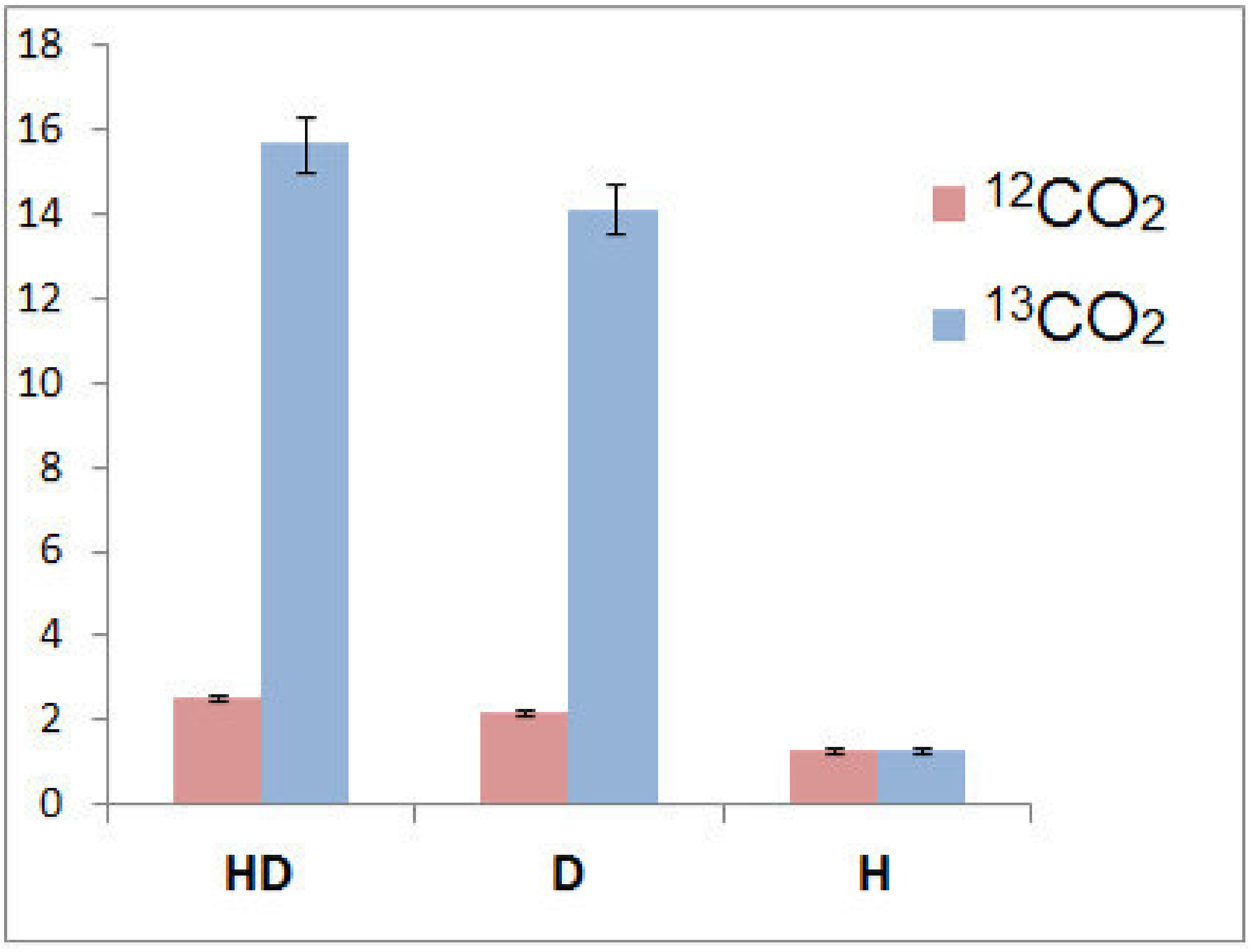


Table S1. OTUs contributing the most to dissimilarity between the experimental microcosms according to SIMPER and significantly different at $\mathrm{P}<0.05$ after Tukey's test for one-way ANOVA. Treatments abbreviations: I - initial inoculum, B - blank microcosms with no carbon sources, H - with humic matter, D - with Daphnia carcasses, HD - humic matter and carcasses combined together .

\begin{tabular}{|l|l|l|l|l|}
\hline & I & B & H & D \\
\hline B & $\begin{array}{l}4,10,25,8,28,29, \\
39,55,64\end{array}$ & & & \\
\hline H & $\begin{array}{l}4,10,6,25,12,8,28, \\
29,39,55,64\end{array}$ & $6,1,10,9,12,16,30$ & & \\
\hline D & $\begin{array}{l}1,4,2,10,3,5,12, \\
25,28\end{array}$ & $1,2,3,7,5,4,9,8,10$ & $1,2,3,6,5,4,8$ & \\
\hline HD & $\begin{array}{l}1,4,10,3,5,25,12, \\
28\end{array}$ & $1,3,7,5,9,4,8,10$ & $1,6,3,5,4,8,11$ & $1,2,19,11$ \\
\hline
\end{tabular}

